\title{
文報 颣分水并
}

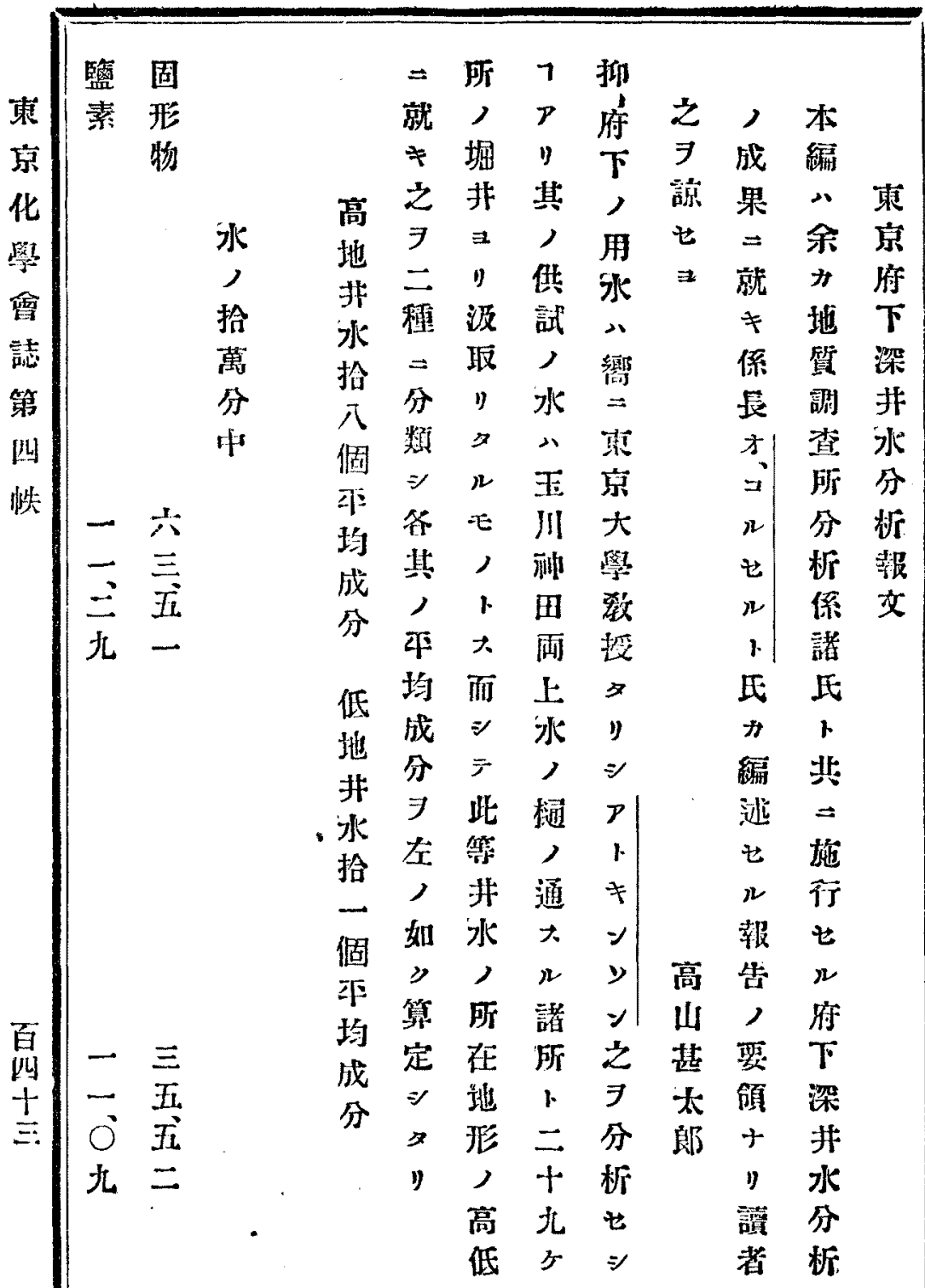


至匹几物分盖事活是乷酸只

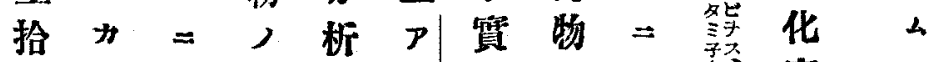

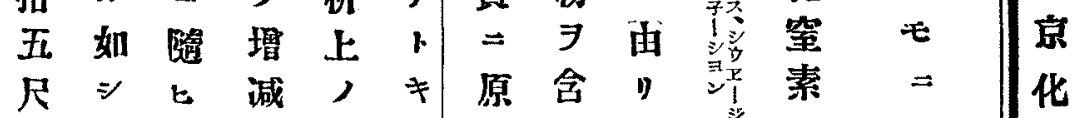

$=$ 然 $テ$ 大數 $キ \neq$ 有

過

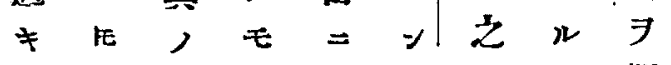

\#東污, 據》

$\nu$ 京物卜

E 低 7 臆 $三$, 明武八

其地溶定宣分大倍串一

䉯掘 收

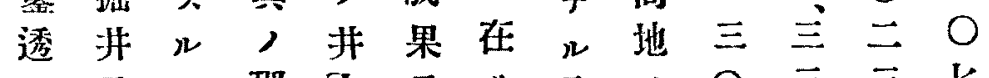

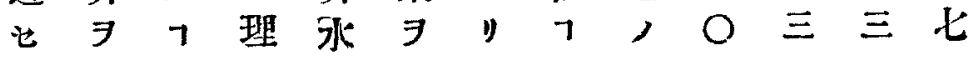

⿰觀愈入八分

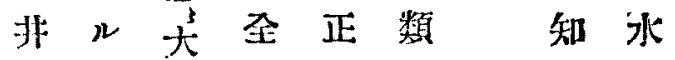

底 $=+\geqslant=\approx$ 川

, 其 $上$ 水其 $\%$ 其

梁, $=$, , 管 $\equiv$,

\#水職土潹明今低

面由壤少 $、$ 本地

算, 大中, 的報了

、深 $几 \Rightarrow$ 多 7 モ

レナモ愈少 7 、要, 六

八, 媣 = 篇

高僅卜”惩 当

地 =信滲

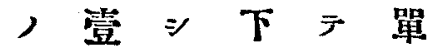

深㭆 $\rightarrow$ 污 =

宣 = 一

蛋遊

白 離

類

似

東

學

霄

誌

第

四

帙

八比 0 兵二四

○ 9 百

全 カ 七 $\bigcirc$ 七 叫

叫 
安報䉼分水井

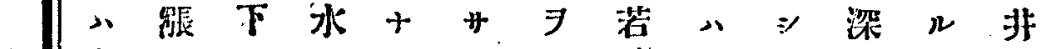

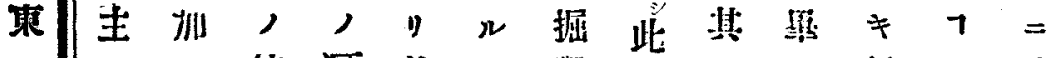
京 1 三 純滙盖所擎, , 竞低大讓

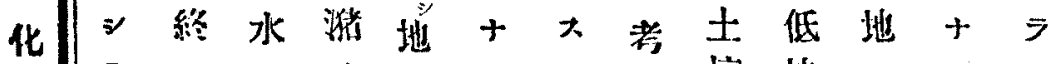
學 $\bar{F}=$ 小, $\pi$ 案壤地, 面士至浃ル表 誌

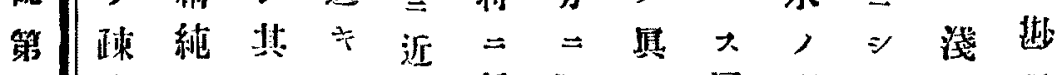

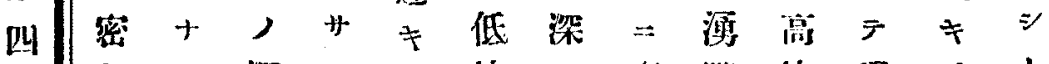

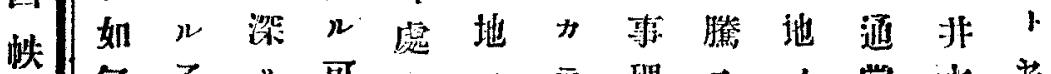

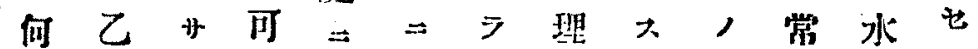
二水 $\exists \neq$ 在在 $\because=$ 非高 $\approx$. 關, 增王》”邓適所水地》然

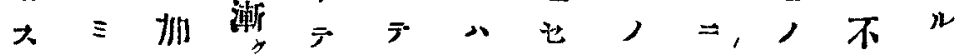

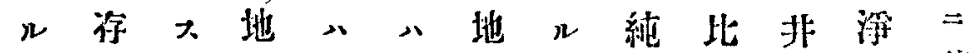

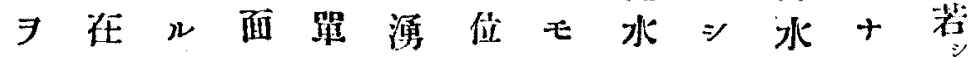
以 $7 \Rightarrow \exists \Rightarrow$ 水, $\Rightarrow$ 脈 $F: \equiv$ 桜 テル焦隔地殆高・止稍》卜

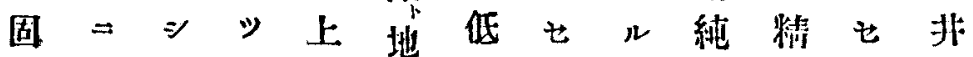

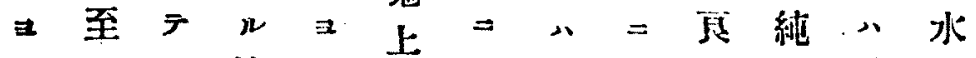

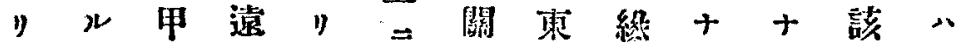
各 一水乡滲澄七京由心分其

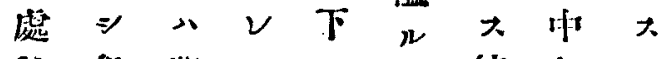
均 但 澌小大

$十$ 十 近 + 此三面所至, $=$ 川察 $三$ 示

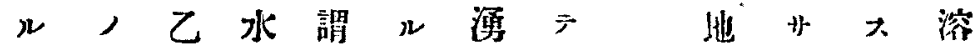
$\exists$ 深 水八表 $\sim$ 治 $モ$ 下 得少八地面宁它韭 $=$ 》 


\section{女報㭛分水井}

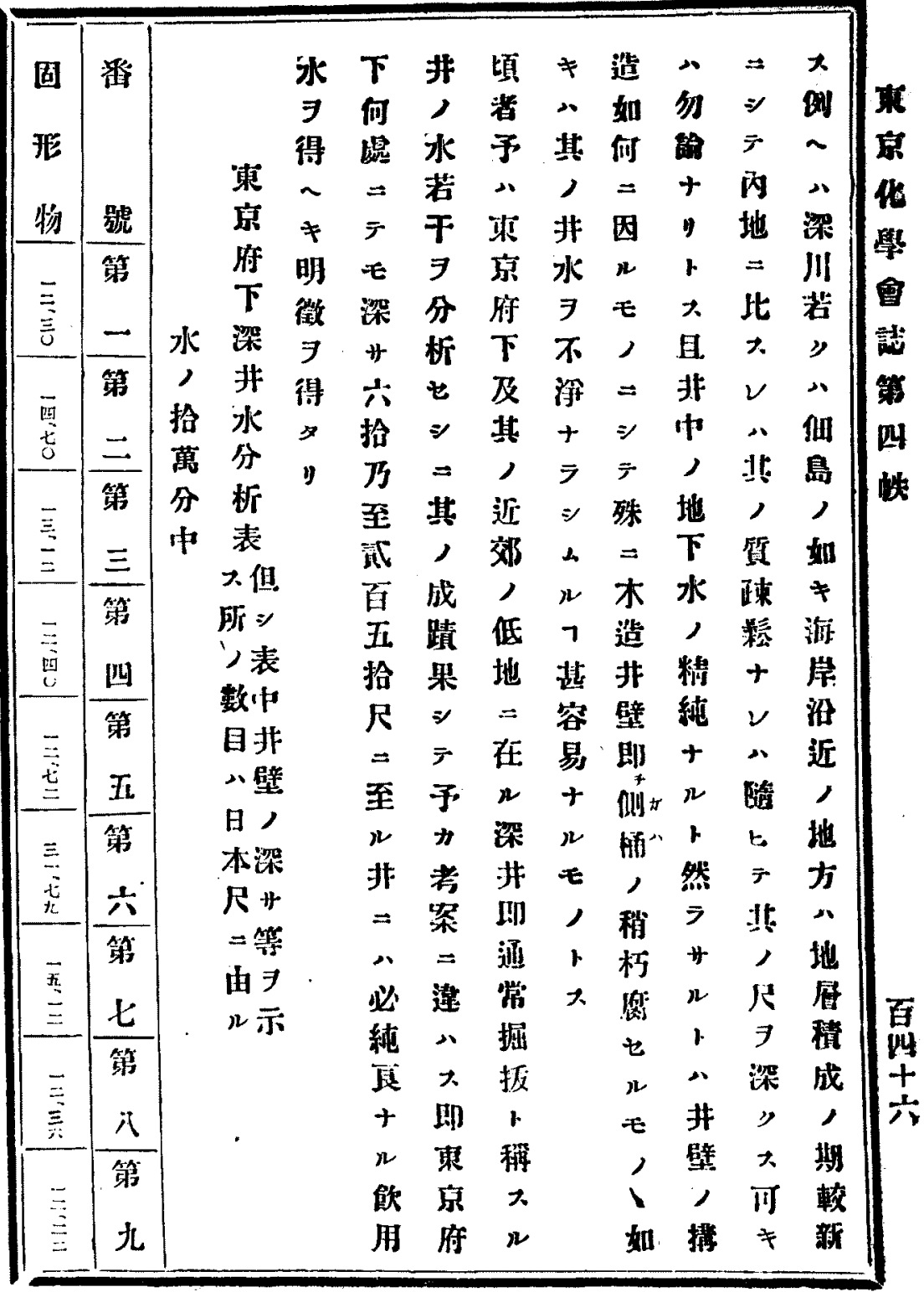




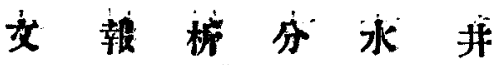

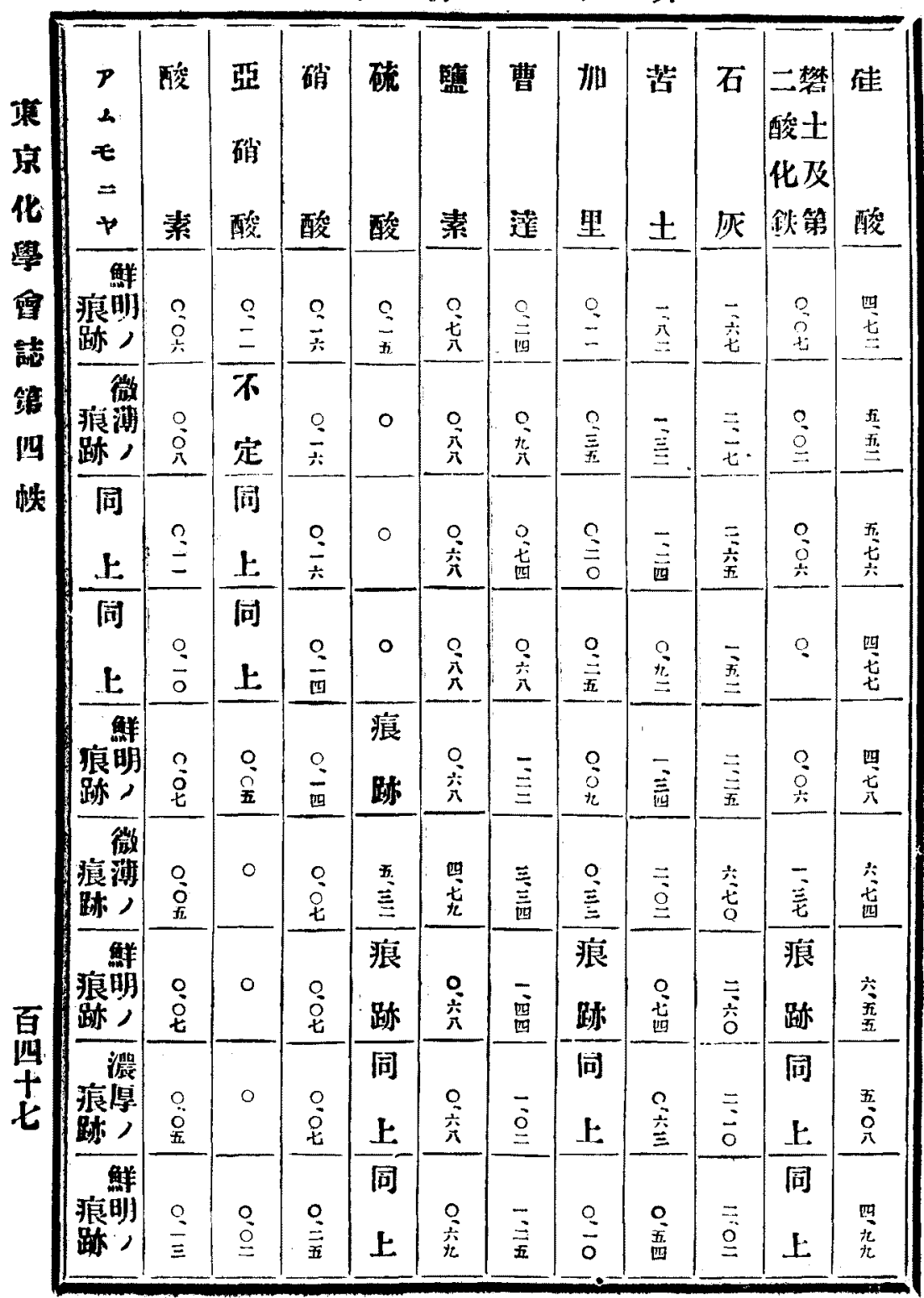


文報析分水并

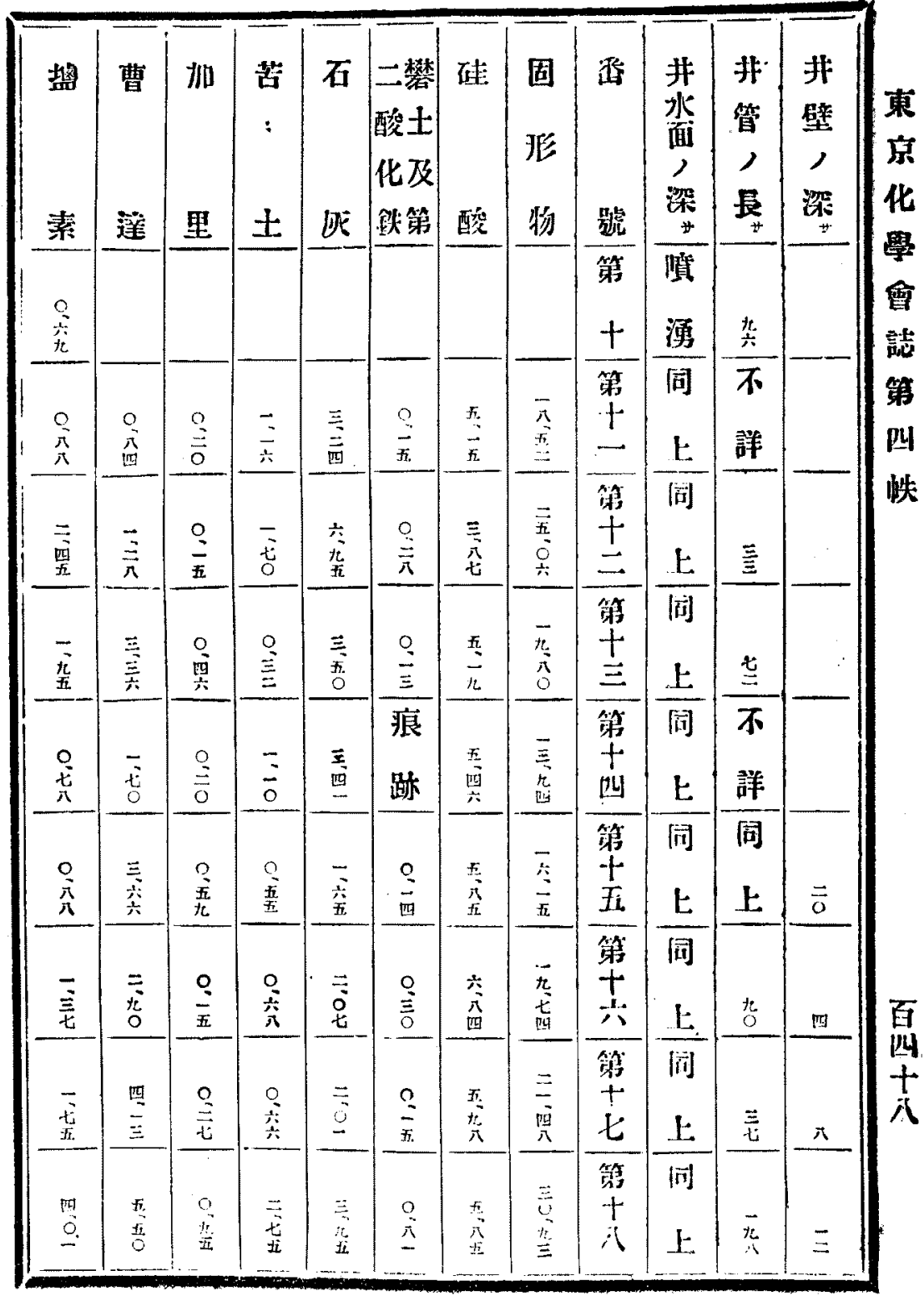


芜却析分水非

\begin{tabular}{|c|c|c|c|c|c|c|c|c|c|c|c|}
\hline 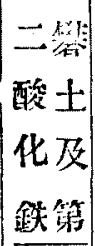 & 㨁: & 固 & 跟 & $\begin{array}{l}\text { 非 } \\
\text { 水 } \\
\text { 面 } \\
\text { 梁 } \\
\text { 深 } \\
\end{array}$ & $\begin{array}{c}\text { 羊 } \\
\text { 管 } \\
\text { ノ } \\
\text { 辰 } \\
\end{array}$ & $\begin{array}{c}\text { 热 } \\
\text { 壁 } \\
\text {, } \\
\text { 梁 } \\
+ \\
\end{array}$ & $\begin{array}{l}P \\
\lrcorner \\
\mp \\
= \\
\forall\end{array}$ & $\begin{array}{l}\text { 酸 } \\
\vdots \\
\vdots \\
\text { 素 } \\
\end{array}$ & $\begin{array}{l}\text { 留 } \\
\text { 确 } \\
\text { 酸 }\end{array}$ & 酸 & 硫 \\
\hline$\frac{O}{7}$ & 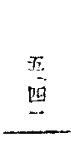 & 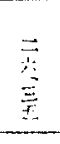 & $\begin{array}{l}\text { 管 } \\
+ \\
\text { 九 }\end{array}$ & $\begin{array}{l}\text { 呚 } \\
\text { 湧 }\end{array}$ & 豆 & $\equiv$ & 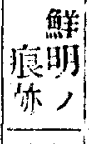 & 园 & 8 & $\stackrel{3}{\Xi}$ & \\
\hline ? & 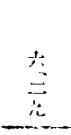 & $\begin{array}{l}\text { A } \\
\text { c } \\
\text { in }\end{array}$ & $\frac{\overrightarrow{6}}{+}$ & $\mathrm{Li}$ & $\begin{array}{l}\text { 尔 } \\
\text { 謨 }\end{array}$ & 苂 & $\begin{array}{l}\text { [ii) } \\
.5\end{array}$ & $\frac{0}{\pi}$ & 0 & $\frac{O}{\dot{t}}$ & $\begin{array}{l}\text { 痛 } \\
\text { 䟽 }\end{array}$ \\
\hline $\begin{array}{l}\text { 症 } \\
\text { 跡 }\end{array}$ & 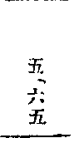 & 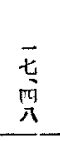 & \begin{tabular}{r} 
管 \\
\hdashline- \\
+ \\
\end{tabular} & $t$ & $\begin{array}{l}\text { 间 } \\
t\end{array}$ & $\vec{E}$ & $\begin{array}{l}\text { (间) } \\
\text { L } \\
\end{array}$ & $\begin{array}{l}Q \\
\frac{Q}{\lambda}\end{array}$ & $\stackrel{0}{0}$ & $\stackrel{و}{\stackrel{g}{*}}$ & $\begin{array}{l}\text { [⿵门日木] } \\
t\end{array}$ \\
\hline $\begin{array}{l}\text { 同 } \\
\text { 上 }\end{array}$ & $\begin{array}{l}H_{0} \\
\dot{t} \\
t\end{array}$ & 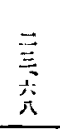 & $\begin{array}{r}\text { 二第 } \\
\pm \\
+\end{array}$ & th & $\overline{\bar{O}}$ & $\equiv$ & $\begin{array}{r}\text { 微 } \\
\text { 症洲 } \\
\text { 胁 }\end{array}$ & $\stackrel{9}{0}$ & 0 & $\begin{array}{l}Q \\
\text { 四 }\end{array}$ & $\stackrel{0}{0}$ \\
\hline $\begin{array}{l}0 \\
0 \\
\therefore \\
\end{array}$ & $\begin{array}{l}\text { 茜 } \\
\text { 䠓 } \\
\end{array}$ & $\begin{array}{l} \\
\vdots \\
0\end{array}$ & $\begin{array}{r}\text { 三第 } \\
\frac{\square}{+} \\
\end{array}$ & $\overrightarrow{0}$ & $\begin{array}{l}\bar{O} \\
\mathrm{i}\end{array}$ & 画 & 上 & $\begin{array}{l}9 \\
0 \\
8\end{array}$ & $\begin{array}{l}\circ \\
0 \\
0\end{array}$ & $\stackrel{0}{\Xi}$ & $\begin{array}{l}\text { 症 } \\
\text { 䟢 }\end{array}$ \\
\hline $\begin{array}{l}O \\
\text { O } \\
\text { 五 }\end{array}$ & $\frac{\pi}{\frac{\pi}{\sigma}}$ & $\begin{array}{l}\vec{\Xi} \\
\overrightarrow{0}\end{array}$ & 证第 & $\tilde{\text { ⿴囗⿴囗十丁 }}$ & $\begin{array}{l}\text { 不 } \\
\text { 誹 }\end{array}$ & 证. & 解 & $\stackrel{8}{O}$ & 0 & $\stackrel{\circ}{\stackrel{O}{\ddot{t}}}$ & $\begin{array}{l}\text { [⿵门日i] } \\
上\end{array}$ \\
\hline 0 & $\stackrel{\text { in }}{\stackrel{\pi}{0}}$ & 咅 & 正第 & $\equiv$ & $\begin{array}{l}\text { 闬 } \\
t:\end{array}$ & $\bar{r}$ & $\begin{array}{l}\text { [ii] } \\
1\end{array}$ & $\begin{array}{l}0 \\
\stackrel{0}{0} \\
\text { 而 }\end{array}$ & 0 & $\stackrel{8}{\because}$ & $\begin{array}{l}{[i]} \\
1:\end{array}$ \\
\hline$\stackrel{O}{ٍ}$ & 回 & $\begin{array}{l}\pi_{i} \\
8\end{array}$ & 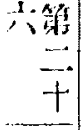 & $\bar{U}$ & 闬 & $\vec{\Delta}$ & $\begin{array}{l}{[1 i]} \\
E\end{array}$ & $\begin{array}{l}9 \\
0 \\
0\end{array}$ & 0 & $\stackrel{O}{O}$ & $\frac{9}{\underline{I}}$ \\
\hline$\frac{?}{2}$ & 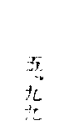 & $\begin{array}{l}\overrightarrow{0} \\
\mathrm{~g}\end{array}$ & $\begin{array}{r}\text { 七棌 } \\
-\vdots \\
+\end{array}$ & 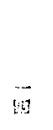 & $\begin{array}{l}\text { 闹 } \\
\mathrm{E}\end{array}$ & 画 & 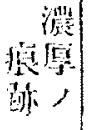 & $\stackrel{9}{\equiv}$ & 2 & $\frac{?}{\sqrt{I I}}$ & $\begin{array}{l}\text { 噍 } \\
\text { 跡 }\end{array}$ \\
\hline
\end{tabular}


妾赫析分水井

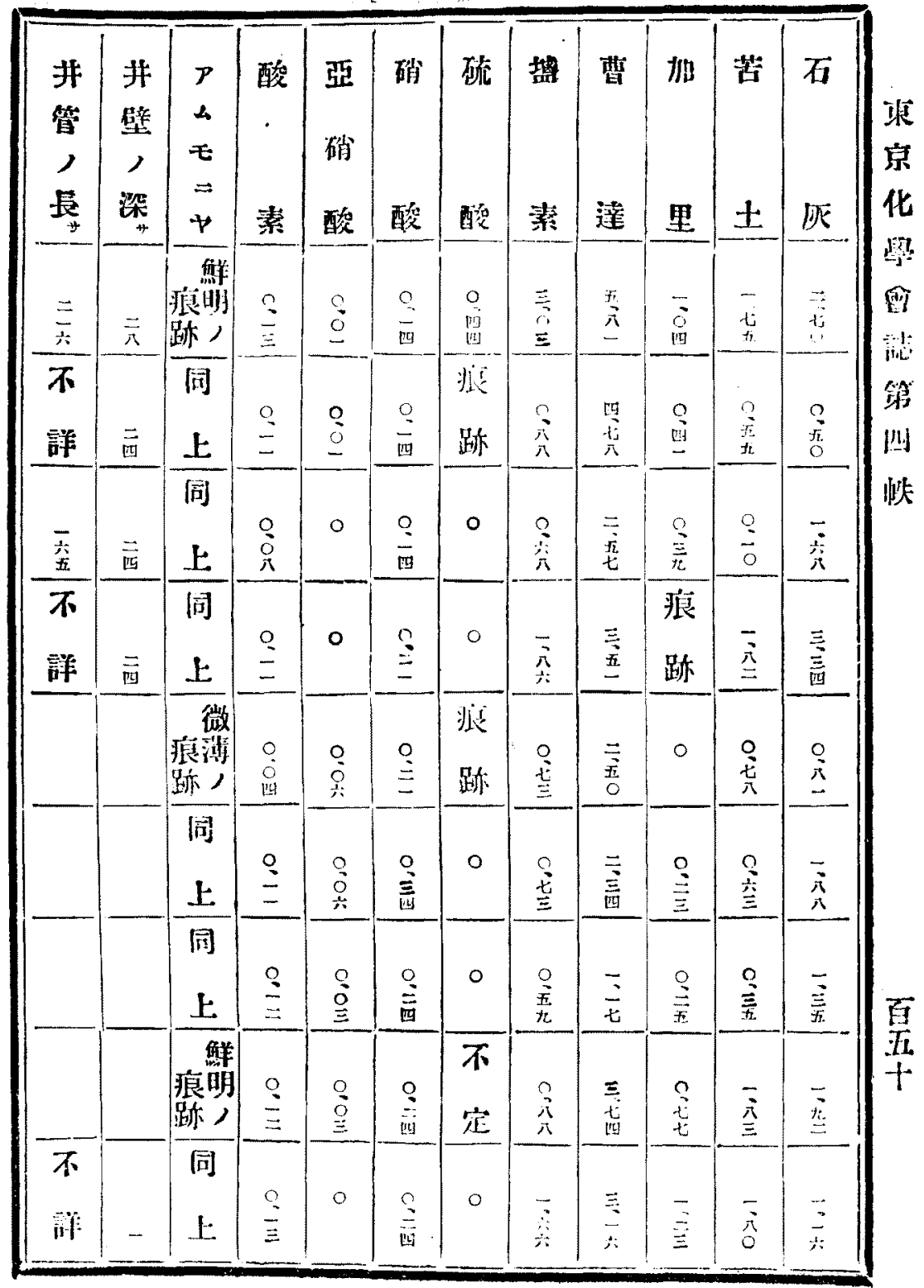




\section{交報析分水开}

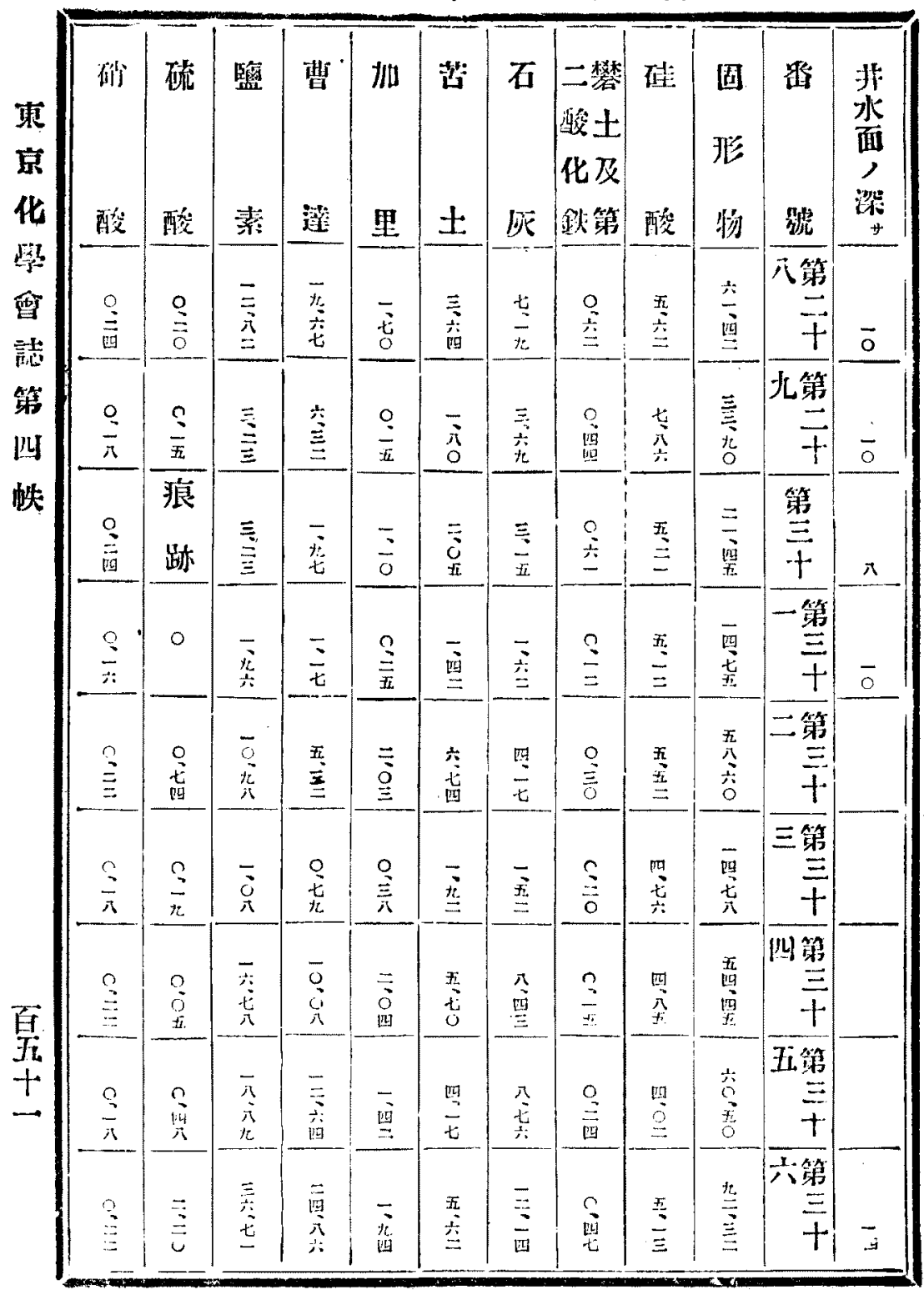


女報 析分水米

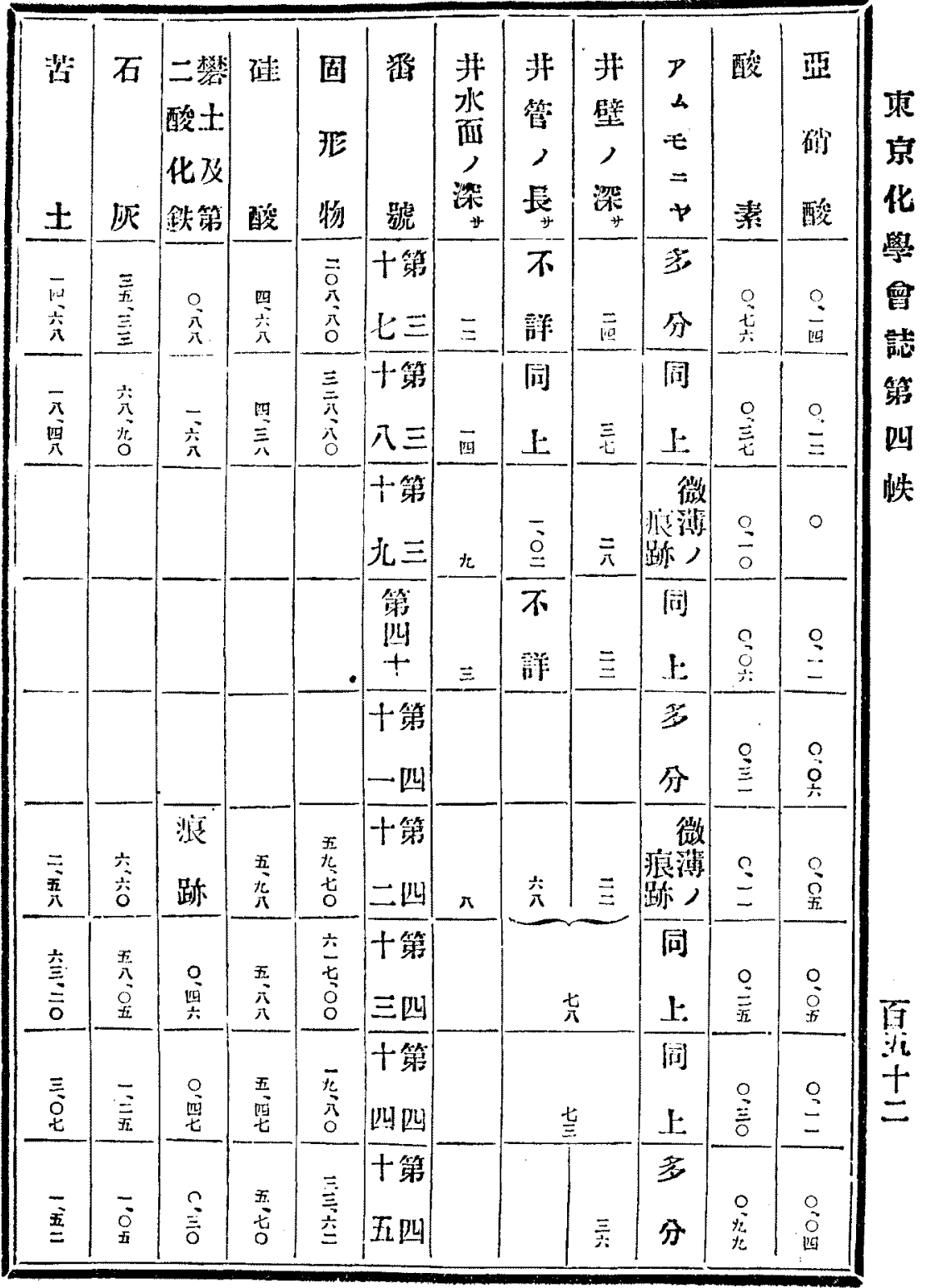


艾垟析分水亚

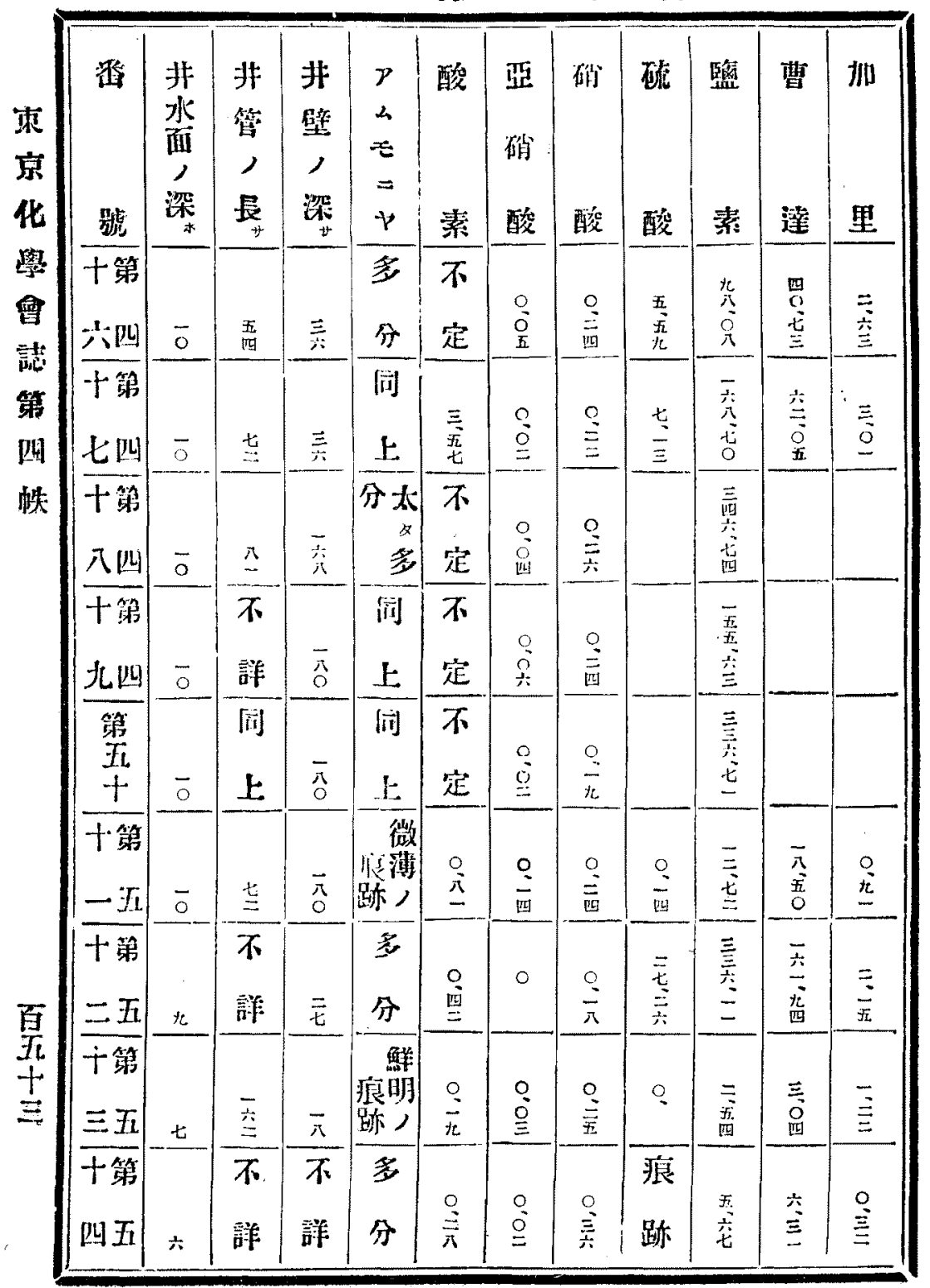




\section{文報析分水开}

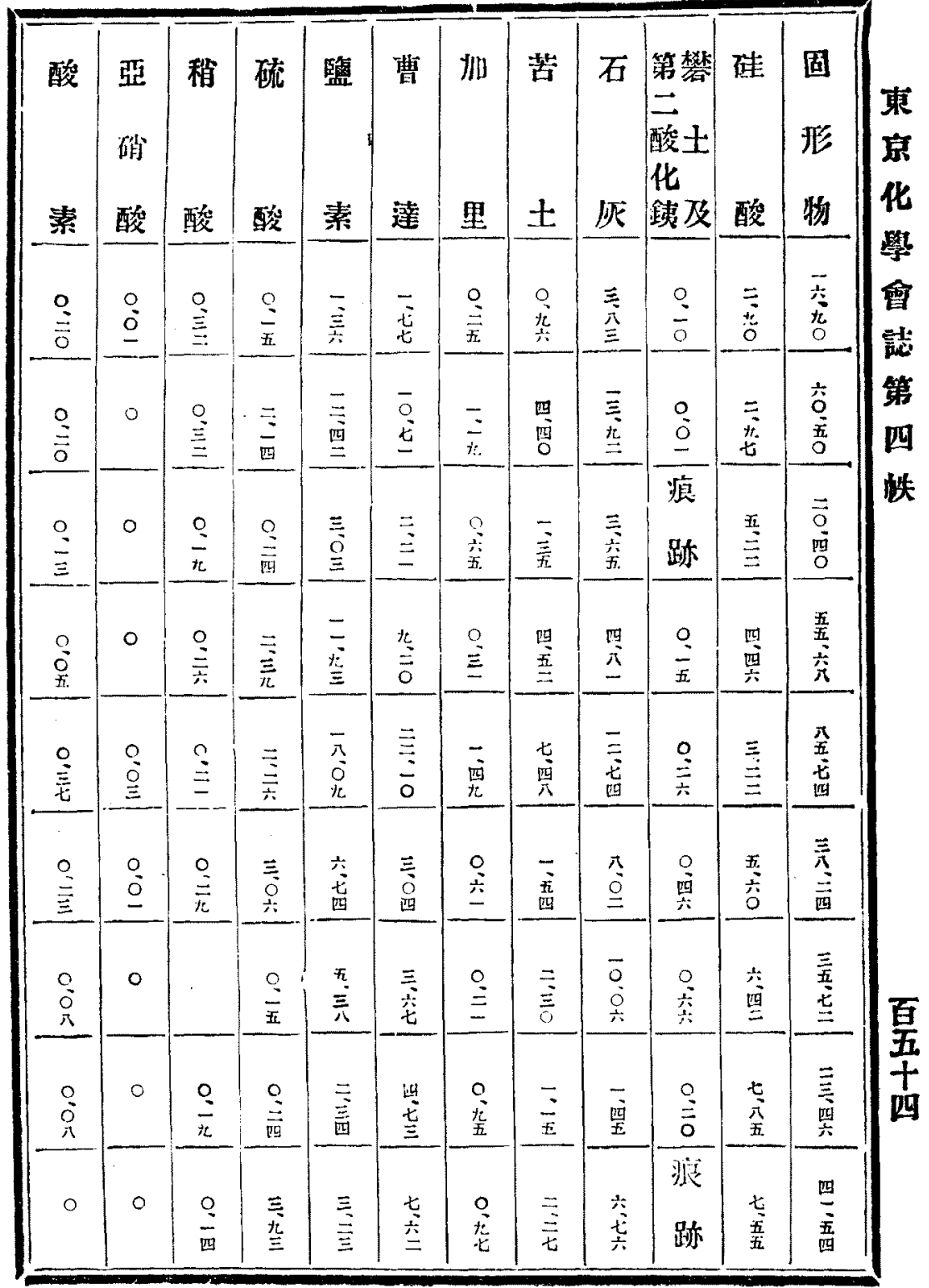


妾壀析分承井

\begin{tabular}{|c|c|c|c|c|c|c|c|c|c|c|c|}
\hline 曹 & 里 & \pm & 矼 & $\begin{array}{l}\text { 二攀 } \\
\text { 酸土 } \\
\text { 化及 } \\
\text { 铁第 }\end{array}$ & 理 & $\begin{array}{l}\text { 固 } \\
\text { 形 } \\
\text { 物 }\end{array}$ & 唬 & $\begin{array}{l}\text { 进 } \\
\text { 永 } \\
\text { 面 } \\
\text { 深 } \\
\text { 学 }\end{array}$ & \begin{tabular}{c} 
井 \\
管 \\
, \\
長 \\
\multirow{\#}{*}{}
\end{tabular} & $\begin{array}{c}\text { 井 } \\
\text { 壁 } \\
\text { ノ } \\
\text { 深 } \\
\text { \# }\end{array}$ & $\begin{array}{l}\mathcal{P} \\
山 \\
\boldsymbol{E} \\
= \\
\vec{\forall}\end{array}$ \\
\hline 杗 & $\bar{i}$ & 呈 & $\begin{array}{l}\text { 四 } \\
\text { 势 } \\
\text { 五 }\end{array}$ & $\begin{array}{l}\text { 演 } \\
\text { 跡 }\end{array}$ & $\vec{E}$ & $\begin{array}{l}\text { 吾 } \\
\text { 音 }\end{array}$ & $\begin{array}{l}\text { 十第 } \\
\text { 五五 }\end{array}$ & $\pi$ & $\frac{\text { TI }}{I_{1}}$ & $\overrightarrow{\mathrm{B}}$ & 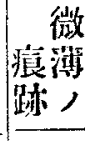 \\
\hline $\begin{array}{l}\bar{O} \\
\dot{\vec{t}}\end{array}$ & $\begin{array}{l}0 \\
\text { 吾 }\end{array}$ & $\bar{E}$ & $\begin{array}{l}\text { 吾 } \\
\text { O } \\
\text { 至 }\end{array}$ & $\begin{array}{l}0 \\
0 \\
t \\
t\end{array}$ & $\stackrel{\text { 五 }}{\stackrel{\equiv}{E}}$ & $\begin{array}{l}\text { 亲 } \\
\text { 亲 } \\
\text { 年 }\end{array}$ & $\begin{array}{l}\text { 十第 } \\
\text { 公开 } \\
\end{array}$ & $\equiv$ & $\begin{array}{l}\text { 不 } \\
\text { 部 }\end{array}$ & $\overline{\bar{o}}$ & 0 \\
\hline $\begin{array}{l}\hat{\pi} \\
0 \\
\text { 花 }\end{array}$ & 音 & $\begin{array}{l}\text { 回 } \\
\lambda \\
\end{array}$ & $\begin{array}{l}\equiv \\
\equiv \\
\text { 量 }\end{array}$ & $\begin{array}{l}0 \\
\text { 五 } \\
\text { 吾 }\end{array}$ & $\begin{array}{l}\text { 公 } \\
\text { 公 }\end{array}$ & $\begin{array}{l}\vec{L} \\
t \\
t \\
\dot{t} \\
0\end{array}$ & $\begin{array}{l}\text { f第 } \\
\text { 七王 }\end{array}$ & $\pi$ & $\begin{array}{l}\text { 同 } \\
\text { 上 }\end{array}$ & 呬 & $\begin{array}{r}\text { 微 } \\
\text { 痕海 } \\
\text { 跡 }\end{array}$ \\
\hline 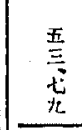 & $\begin{array}{l}\equiv \\
\\
0 \\
0\end{array}$ & 置 & $\begin{array}{l}\text { 吾 } \\
\text { 吾 }\end{array}$ & $\frac{9}{0}$ & $\begin{array}{l}\text { \#. } \\
0 \\
0 \\
\end{array}$ & $\begin{array}{l}\bar{t} \\
0 \\
\text { 音 } \\
\end{array}$ & $\begin{array}{l}\text { 十第 } \\
\text { 八五 }\end{array}$ & $\begin{array}{l}\text { 隫 } \\
\text { 湧 }\end{array}$ & 竕 & 兵 & 0 \\
\hline 立 & $\overline{\overline{\bar{t}}}$ & 吾 & $\begin{array}{l}\equiv \\
\equiv\end{array}$ & $\begin{array}{l}\stackrel{Q}{2} \\
\text { 莣 }\end{array}$ & 吾 & $\begin{array}{l}\text { 吾 } \\
\text { 䒧 } \\
0 \\
\end{array}$ & $\begin{array}{l}\text { 十第 } \\
\text { 兀五 }\end{array}$ & $\therefore$ & $\begin{array}{l}\text { 不 } \\
\text { 詳 }\end{array}$ & $\overrightarrow{\vec{\lambda}}$ & 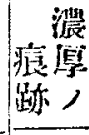 \\
\hline $\begin{array}{c}\pi \\
j \\
x\end{array}$ & $\begin{array}{l}0 \\
y \\
y \\
t\end{array}$ & $\equiv$ & 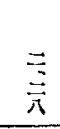 & $\frac{?}{\dot{t}}$ & 鼋 & $\begin{array}{l}\overline{\vec{z}} \\
\text { 䓎 }\end{array}$ & $\begin{array}{l}\text { 籍 } \\
\text { 分 } \\
+ \\
\end{array}$ & $=$ & & $\bar{E}$ & $\begin{array}{l}\text { 同 } \\
上 \\
\end{array}$ \\
\hline $\begin{array}{l}\Xi \\
\text { 亲 }\end{array}$ & $\stackrel{\stackrel{0}{\dot{\bar{I}}}}{\text { 五 }}$ & $\begin{array}{l}0 \\
\text { 吾 } \\
\text { 回 }\end{array}$ & $\frac{0}{1}$ & $\begin{array}{l}\stackrel{0}{0} \\
\text { in } \\
\text { in }\end{array}$ & \begin{tabular}{l}
$t$ \\
\multirow{\lambda}{*}{} \\
0
\end{tabular} & $\frac{\Xi}{E}$ & $\begin{array}{l}\text { 十第 } \\
\text { 一六 }\end{array}$ & $\equiv$ & $\begin{array}{c}\text { 不 } \\
\text { 撛 }\end{array}$ & 亲 & 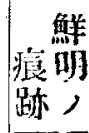 \\
\hline $\begin{array}{l}0 \\
\text { 分 }\end{array}$ & $\stackrel{\text { 五 }}{\text { 五 }}$ & $\overline{10}$ & 酋 & $\begin{array}{l}0 \\
0 \\
0\end{array}$ & $\stackrel{\underline{\Xi}}{\underline{\Xi}}$ & $\begin{array}{l}\text { 三 } \\
\text { 䒔 } \\
\end{array}$ & $\begin{array}{l}\text { 十第 } \\
\text { 二公 }\end{array}$ & 四 & $\underset{\vec{\lambda}}{\vec{\lambda}}$ & 三 & $\begin{array}{l}\text { 同 } \\
1\end{array}$ \\
\hline & & & & & & & $\begin{array}{l}\text { 十第 } \\
\text { 三六 }\end{array}$ & 六 & $\begin{array}{l}\text { 不 } \\
\text { 棓 }\end{array}$ & $\begin{array}{l}\text { 不 } \\
\text { 詳 }\end{array}$ & $\begin{array}{l}\text { 微 } \\
\text { 源薄 } \\
\text { 跡ノ }\end{array}$ \\
\hline
\end{tabular}




\section{文報䉼分永开}

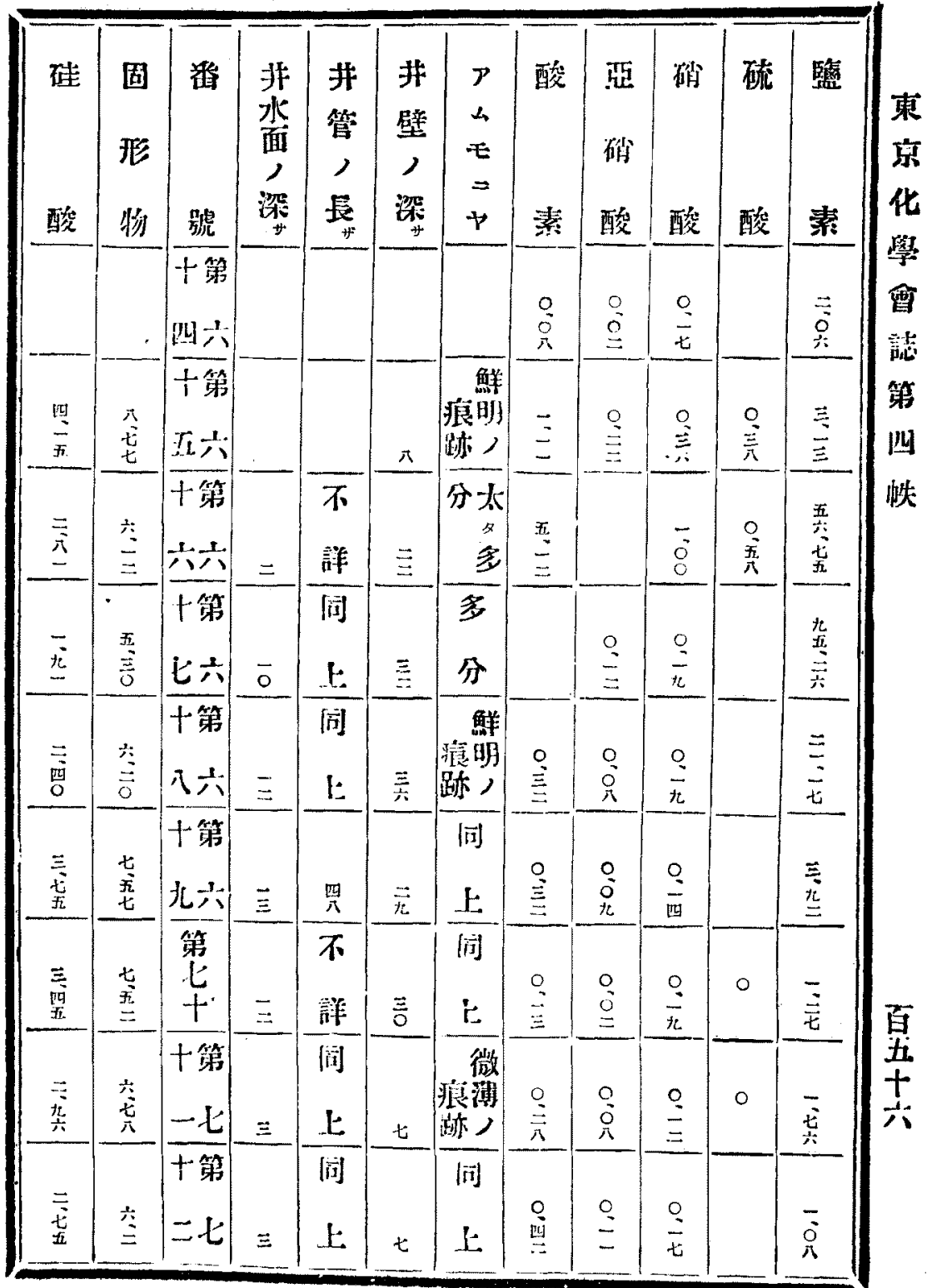


妾韩析分水并

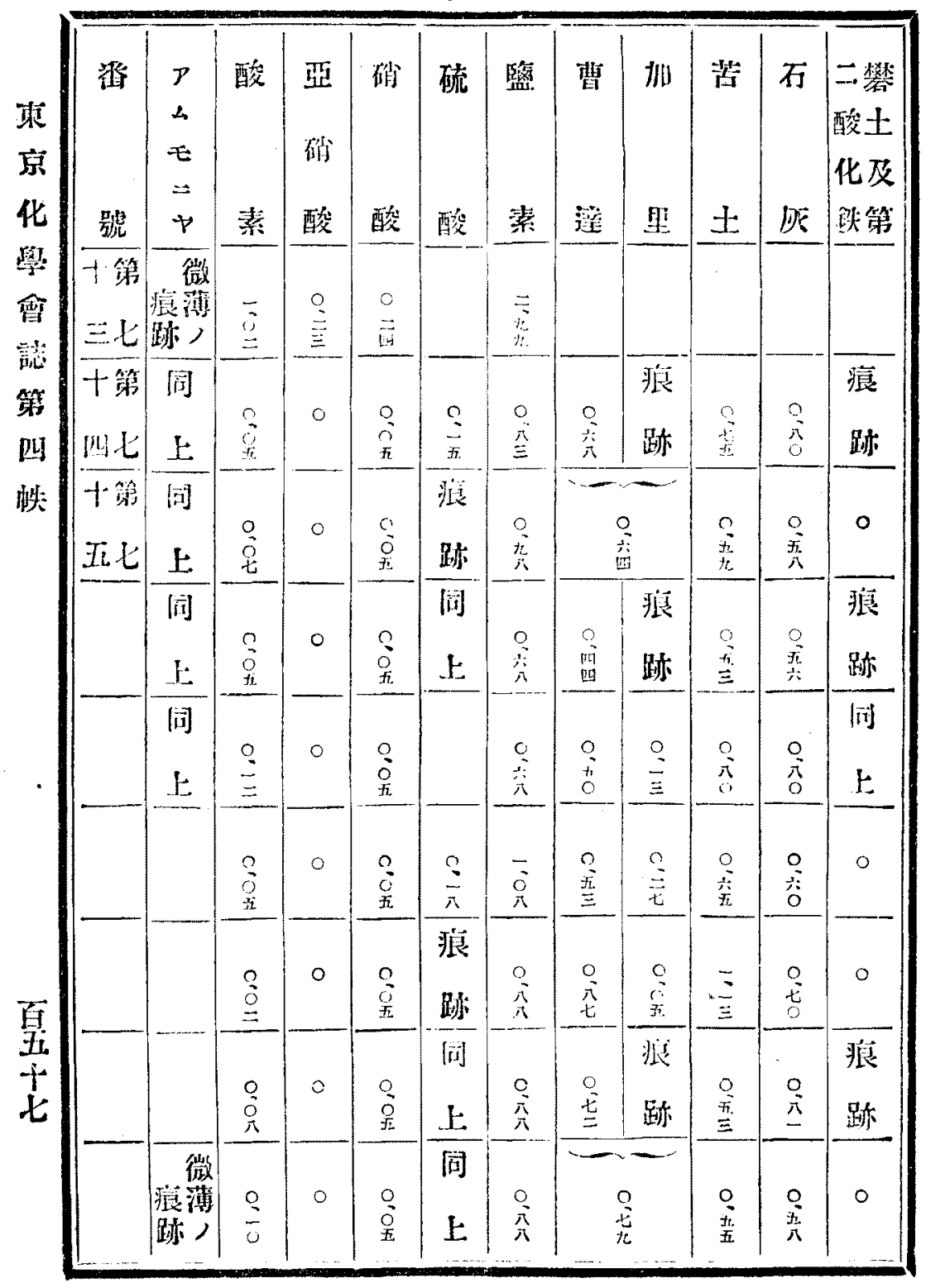


老郝析分水北

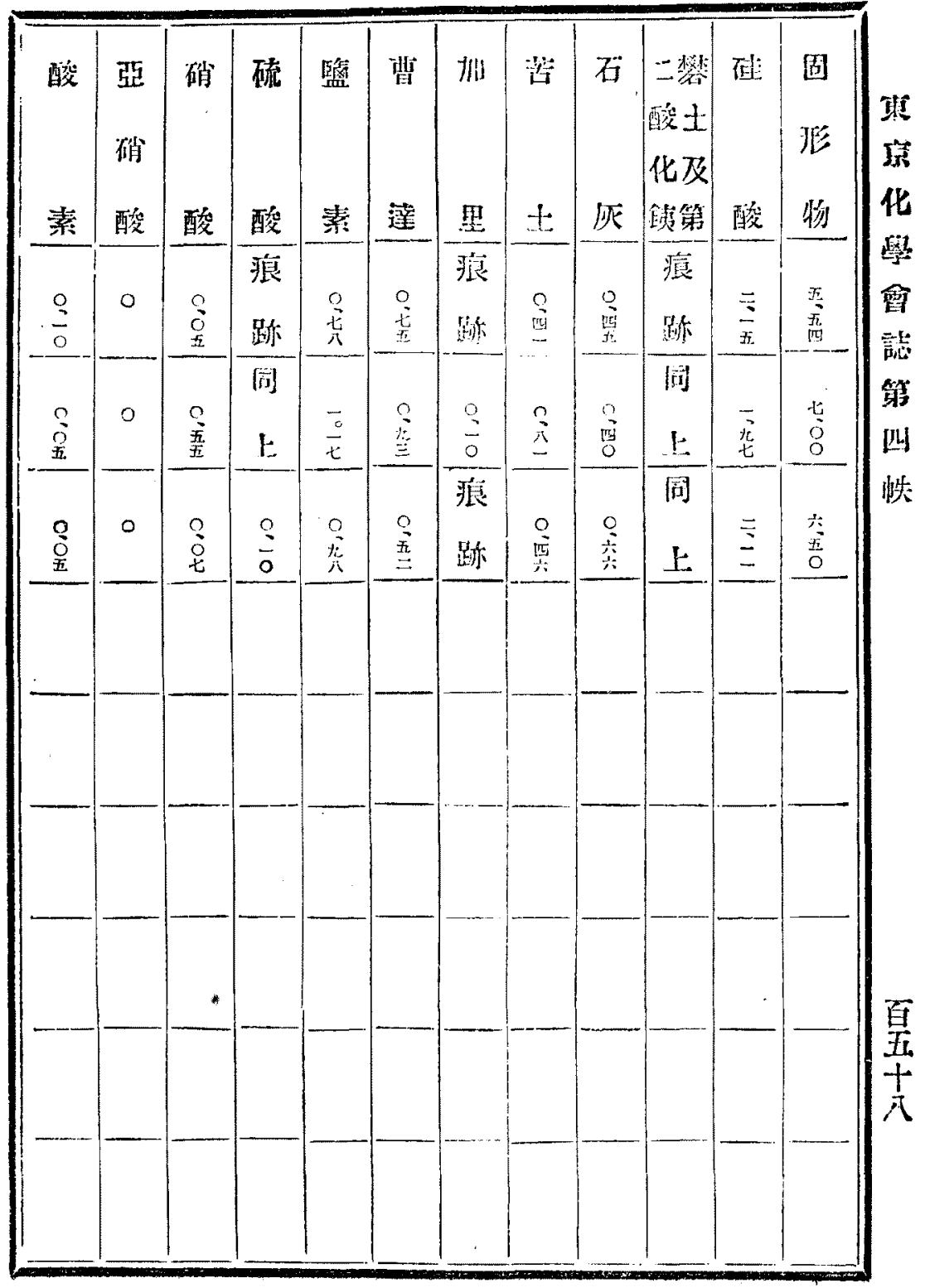




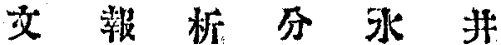

十八號 入管號 地 第

琹 三全”全十”

宗 號

化

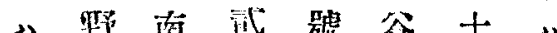
千 町 $\bar{x}$ 拾

佳 三町七浅上號田全全中韭

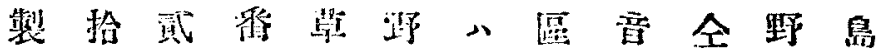

䄉 七 拾地

第

所 唯

企中旸百村郡

地 潅

第地

粐

二 第

+ 二 籍

四十二”十地榃滔五

喼 二十全六

川號跟下暍

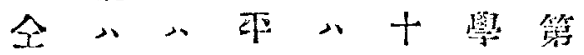

上. 企全有 金

新今

稆

非

第 吉 的阿天

二 原时町町全籍全

百

四櫵 +

號 队

队 號

宗 琎 潘

地

地六地地

號

第 入第 第

八小四二

踋石號 號

It

$+$

十江三或拾

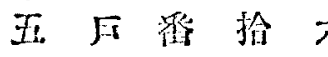

碞

浽

管十今

小二川

$\vec{a}$

路 颔

町

小

拾 企

路

全 $\mathrm{I}$ 箈 地

上目 :

$+$

第

籍 筑 -

二 三跣

管 入

武
丁

II

遌

新 全

沙，千百

訪五五

町百拾

\#拾 四

叫氛 証

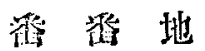
地 地 


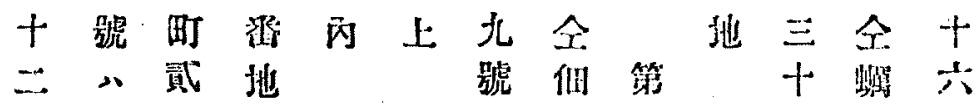

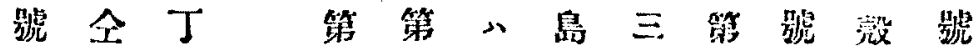

“田自第四四全監十三八町入

全町武四十十上獄问十宗三全

高武然十五三署號二橋丁上

輸丁地七號號符㩲八號區目

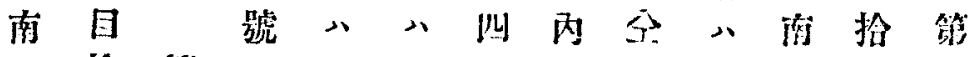

町拾第八芝全十入企蓝武二

拾入四企區下號第船企町的十

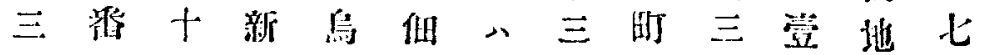

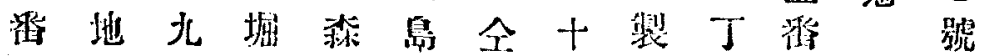

池號町町拾上七水目地管

第 “三臺王號所拾三日

第五全拾潘潘第、武第十本

五十西武地地叫全第游三儿榀

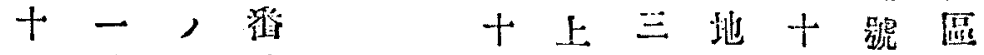

三號 久地第第一

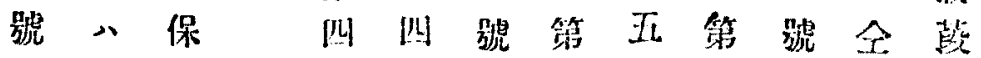

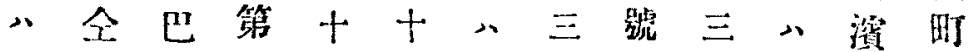

企車町四共四全十”十企时九

白町哟十號號上公全三栤武搌 金武拾八川八號上號挽丁地

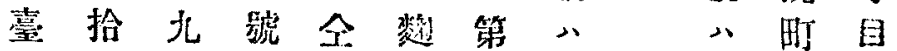

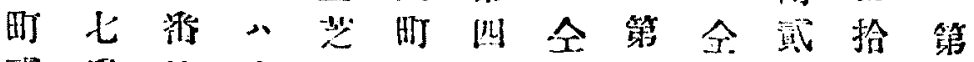

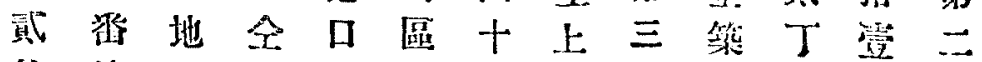
拾地南武警二十地白㧘十

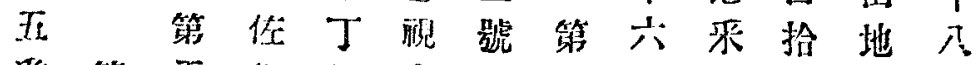
番第五久目酸、三號女三號

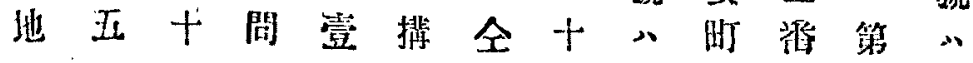


取七但妙摩六心號八町川

東也十三正郡十泉八揇拾區第筫

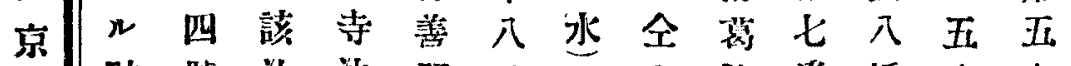

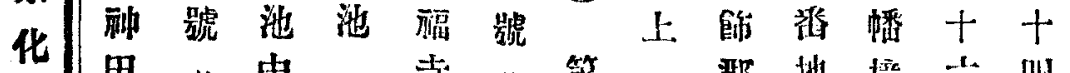

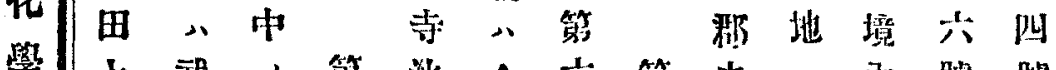

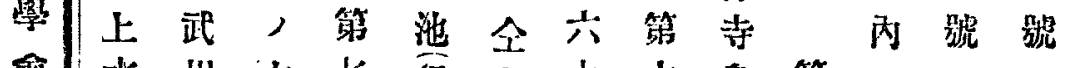

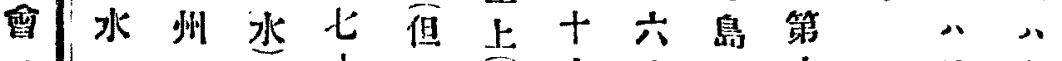

誌東策第品全

第 第一错 $三$ 號无干十五川赤

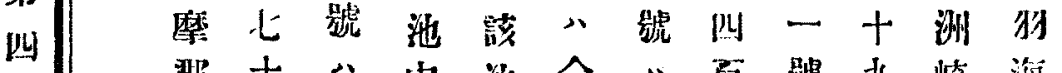

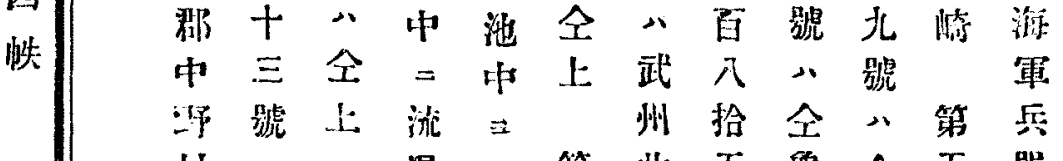

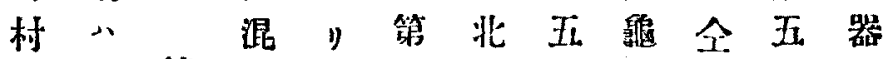

全第大流六蓄滛濢森十局

第上比

七但十泉 $九$ 䂙壹町號內

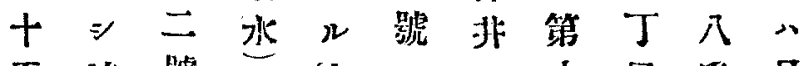

五該號一水八, 六目留品第

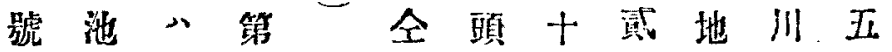

八中武七第上溜三拾噯十

小寻州十六但但號无第境五

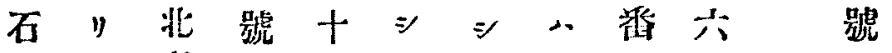

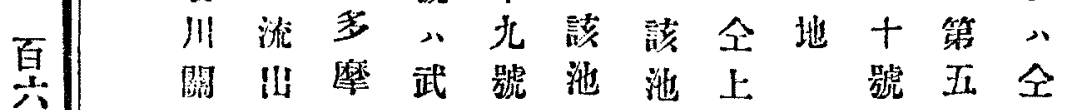

口大郡州入中中第入十上

$\Rightarrow x \equiv$ 北武, 第共本八但

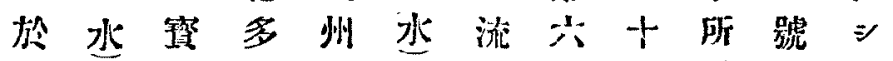

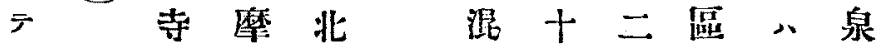

汲第池郡罗第大则號元深 水 
第第予分里，表所水至亲右

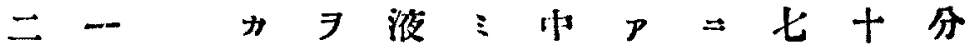

監固所云 $\exists-, y=1$ 四析

素形見 > 洼解諸

八物 $\quad$ + 㨫 7 愐

二八掉》シ下

乃五水 $v \quad \bar{y}$ -

至十, 八其 7 目

三分拾純，裂膫

分 9 萬息所 7 然

$\Rightarrow$ ”分 + . 公鄙 $\Rightarrow$

曰罗中心, 低

多多领有試

$\Rightarrow ;$

ラ サ

用

少

n 7

水

,

t:

7

,

原

率

ᄏ

超

過

t

H

n.

7

要

大.

機，以

物 水

习习敢

酸 酸

化 性 颈

せ 1 辨

$=+t$

472

几, 但

二後

型之酸

大 $=$ 素

n過

所 滿

, 绳 计

酸 酸 ル

素加 項

二五號表

其號中心

, “獨七

涌 融 第 拾

讦田五五

上 上 個

水五,

所 = 跣水

, 係 $\exists$ 侗

果

京

化

學

水此分

量但》析

芕 $\approx$, ,

\#第 外 成

ラ五八靕

大十皆 7

且五梁示

性號井

蜆心水モ

展海二,

自軍

深 兵 $\bar{y}$

非器 第 即

水局六第

1. 擈十一

異丙五號

十, 號乃

泉乃至 


\section{女報 析分永井}

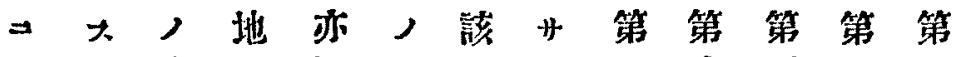

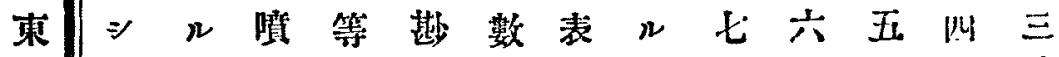

京 F所水處 $三$ 内 $=$ 有 $>$ 缩石硫

化即謂䥷々 々

精 表 井 $\Rightarrow$ 学居示

良面十穿

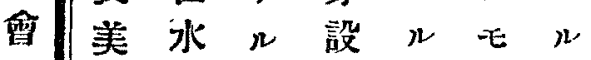

誌質, モ世十

第十㴤, ル多北

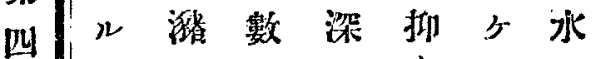
$\exists$ 大 $\neq$ 多レ,

帙 常等勇掘束比分

卜モ”厉矿亦析

大, 面北术超成

其 $=シ=$ 街過 果

, \テ

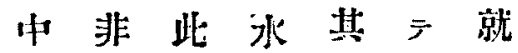

稍大程婑, 飲 $\neq$

不县, 混環用テ

淨 $=$ 井涌 園 $\Rightarrow$ 逐

十地水 $三$, 佔一

モ 單地地儿撸

臭

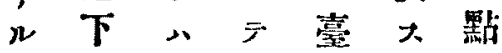

機山酸炏 酸

物モ八及”

$\exists=0$ 苦 八 酸 $ヤ$ 五士 乃 化多乃八至 せ七至合十 $\Rightarrow$ 留 一 $三$ 分 A 硝正 $\div \geq$ 酸 分二"

$=八 \geq+\frac{1}{3}$ 裂僅》分 カ 大 $\#$ 䒚 $\equiv$ $n=\pi$ 少 所痕 $三$ 芕 ノ跡 \#カ十

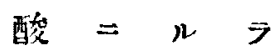
素止 7 \# $\therefore n$

$\begin{array}{lll}0 & 1 & 1\end{array}$

吾

$\exists$ 1)

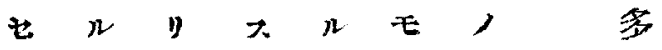
純漈几间, 率办

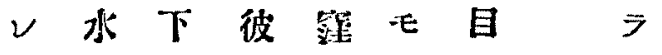




\section{文報析分水非}

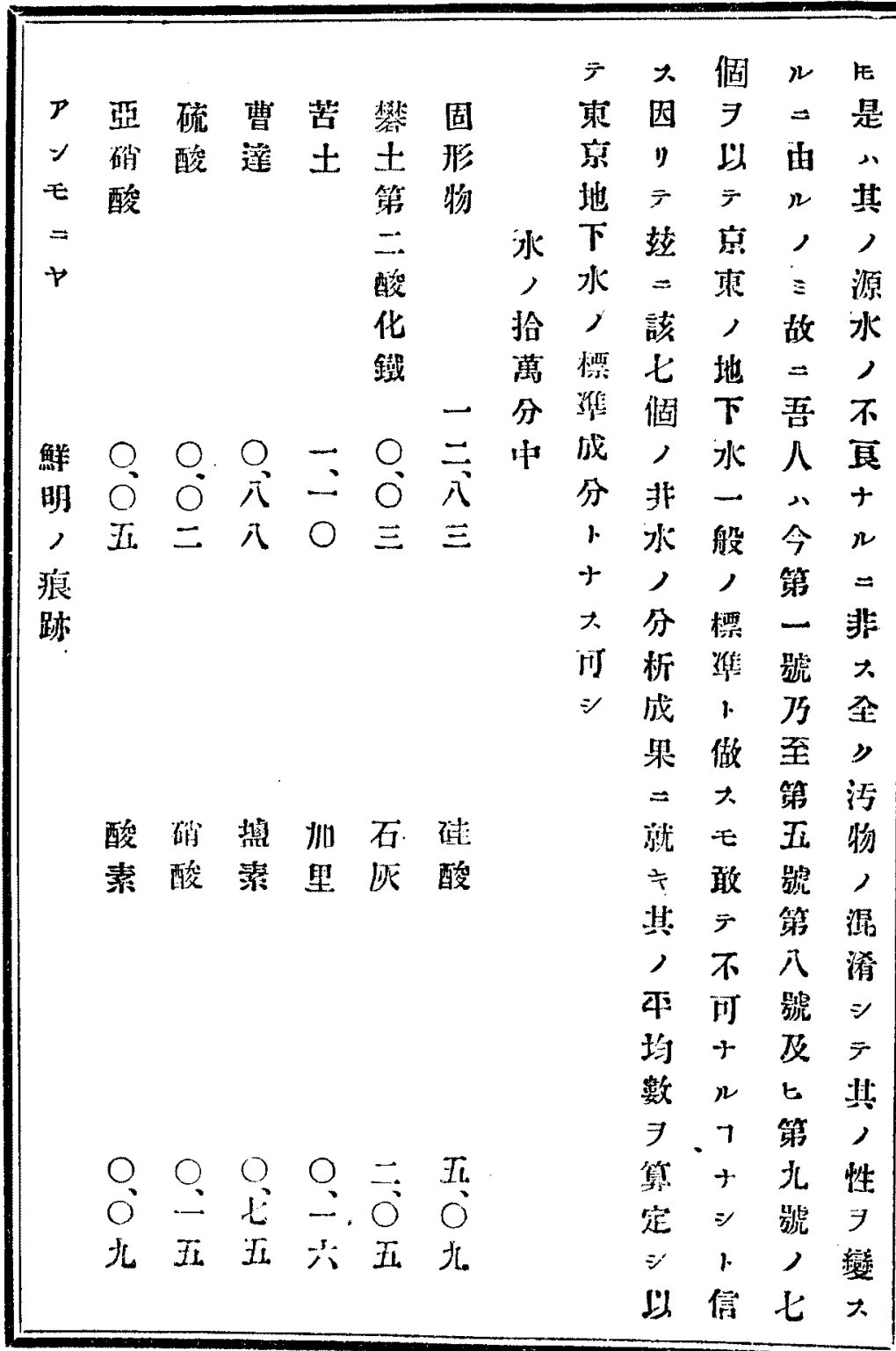


所滴二 0 ， 今 $⿻$ 因卜 $⿻$ 多定凡 束 含 也五分 $v$ 此

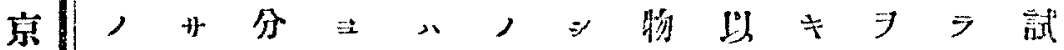
化 盐 學 溸七刀少形拾 分; 少干物九理量造諭此趾也

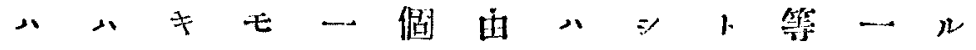
誌三唯分, 五, “一堅 $>$, 七叫

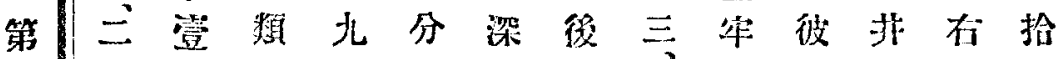

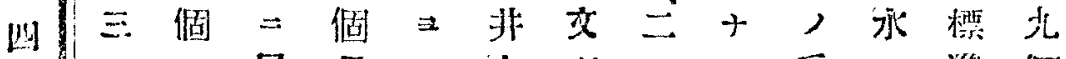
帙

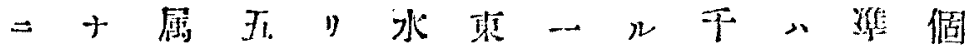
”，

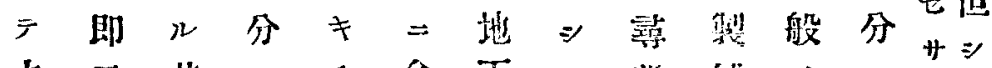

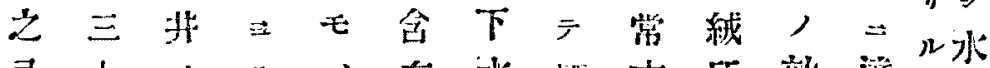

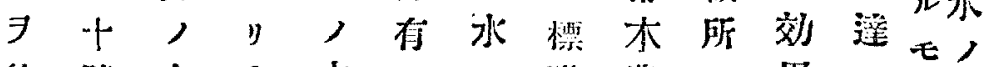

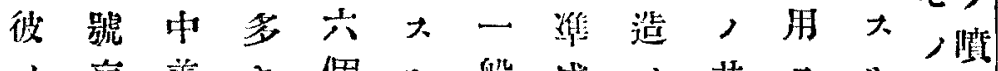

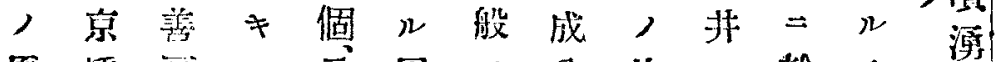

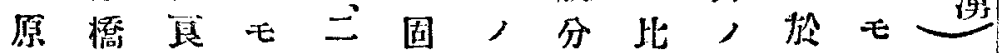

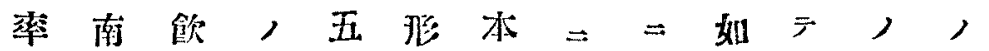

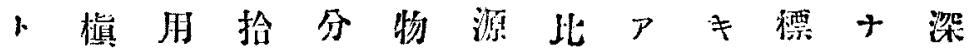

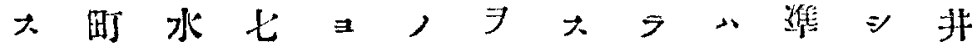

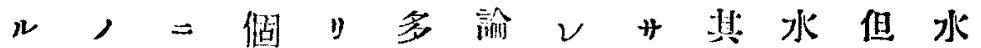
所井必卜少富次入上, 上”“ 百人水須 $大 \neq=70$ 比韭相稍其

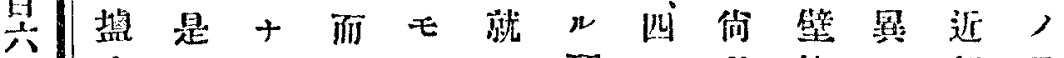

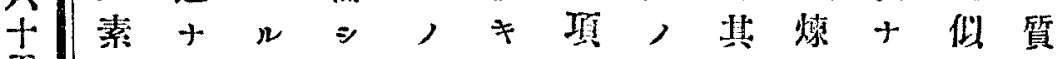
王 量》原 $;$ 拾之心多, 不方九,

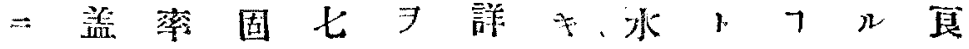

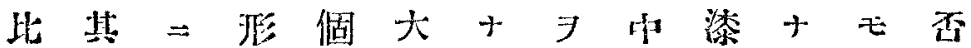
大, 合物五则”晃, 死”, - 
交 報 析 分 水 井

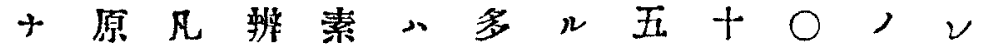
$n$ 素井 7 及来 $\neq$ 飲十儿, 水”

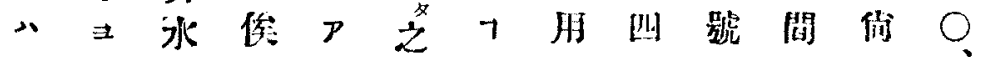

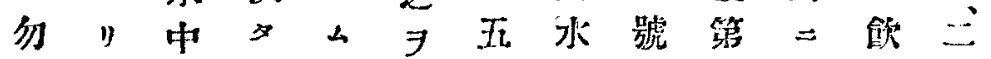

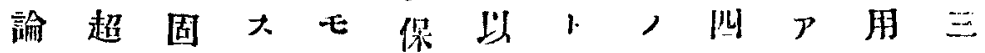

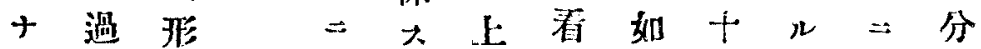

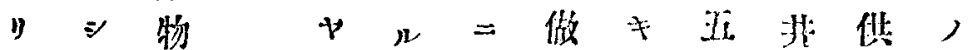
卜日五, 能泾三八號永シ成

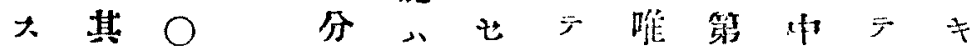

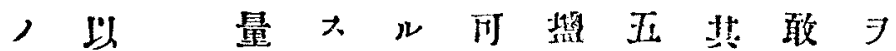
酸上七第》十素十, 天見 素,

モ 萝

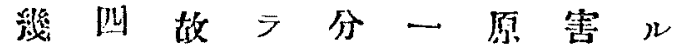
頗 占十 茤 二 量 連 + せ

r

モ 倍无之第少第, 儿諭 , 號 $\exists$ 五 $三 A$ 数 7 此 萝三“饮十”十日十,

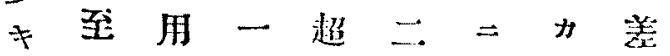

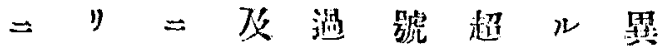

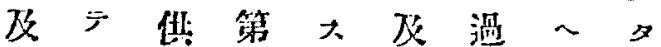
$>$ 八

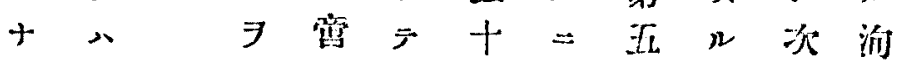
$\nu$ 其 以 $=$ 果二過十七 $==$ 八, $\doteqdot$ 盐 $三$ 䛸 $干$ 叫, 固些 其監其素テ ハ少號五源微

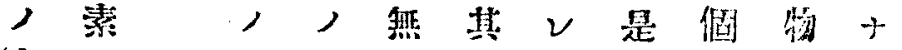
水,

質 分 不 $\equiv$ 是

, 量

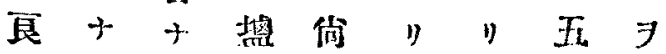
不モ ,$+ \ni ル$ 素誉但趴序以 展 几大古分是 $三$ 管至 7 酸否, 寸第二五此

棸 等 化 繁 合 誌 第 미 怢 


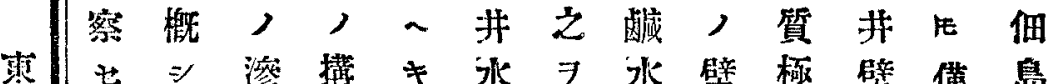

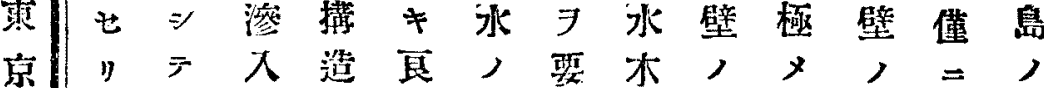
化即水 $ᄏ$ 八韭分 $、$ 壁深

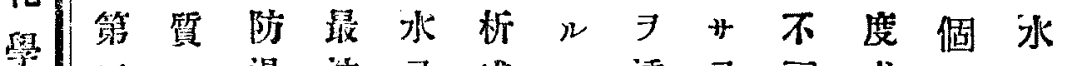

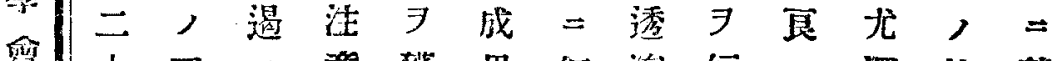

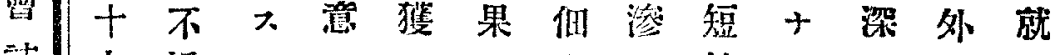

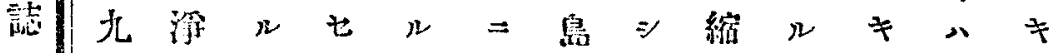
第 號 叫第ル可 7 期》共容八是ノ不入 制 三 韭1

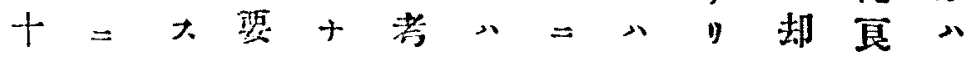

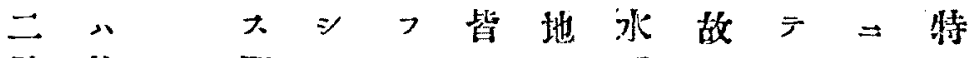
號 其 即 $卜 2$ 饮下留 $=$ 百 $=$

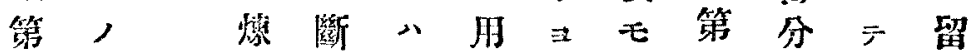
叫壁石定未二”亦三中且意

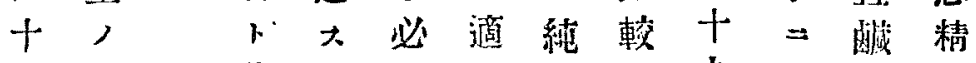
七稍沵 几

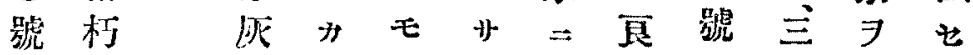

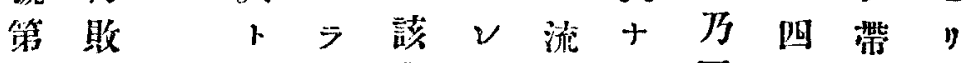

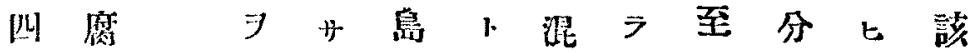

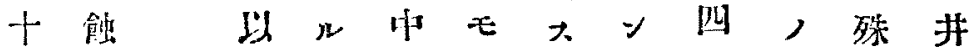

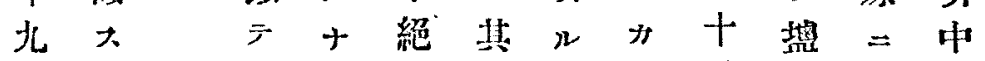
百號n修りュノ

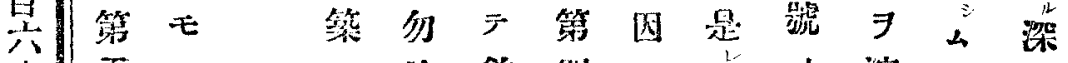

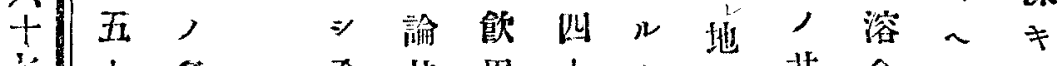

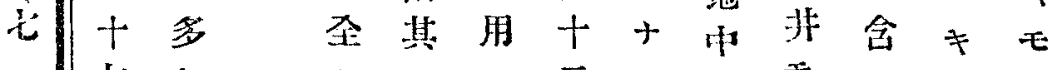

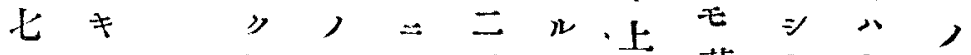
號 7 污开供號可虏若其其 $>$ 等觀水壁大, $大$, 萁,,$\nu$ 


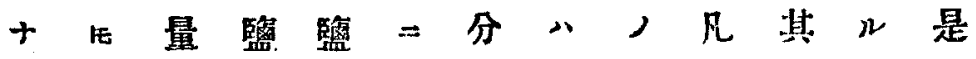
斯曹ト $、$ 歐, 歐多本, モ十 $\sim$, 䢰 + 搆上石州 学試水, 》

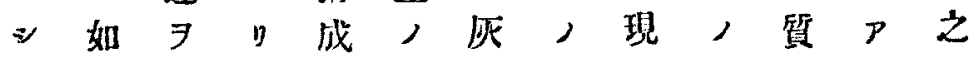
キ抱若 7 非苫非二韭 八和》几水士水其水害即反 石 、小 $=$ 小中, 中第

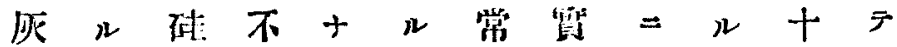
若 = 酸充 $\neq$ 川 》要 1 分所”晃 7 打毫號壁

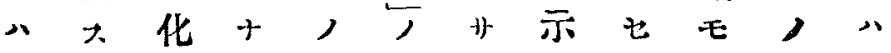

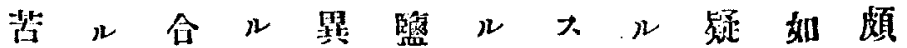

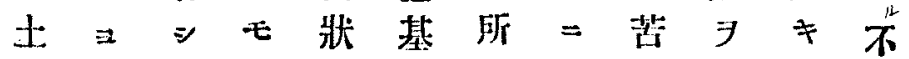
ノリテノ+性二護土容是底 一遥現徃り成 $三 川 \cdots ッ+$ 部二存々ト分デ每可》ル

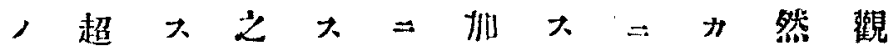

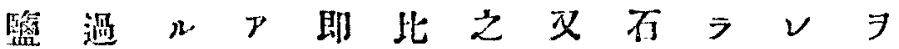
素大モり監

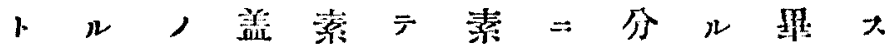
化, + 些分稍硫示 $\Rightarrow+$ 䆓 $v$ 合侧少, 多酸大比》非比

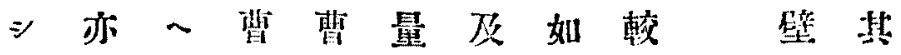

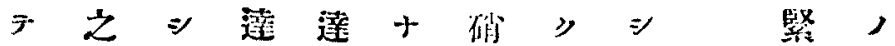
存十呵, 上小酸珪 $匚$ 密水

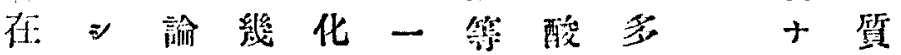
大. 1 監分合軎, 分量 ル 溸 シ モ酸, † モサ, 宸亏办性荠心

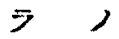
斗善 $\checkmark$ 宣

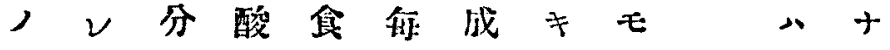


踓下 $\ni$, 茈低十几在, 顆, 初

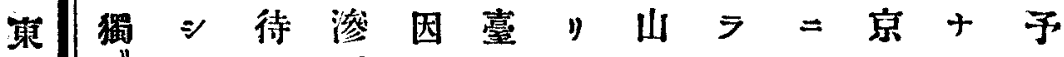
京彼一 $\Rightarrow$ 下地果脈

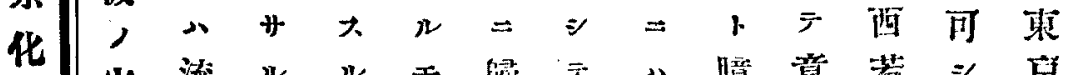

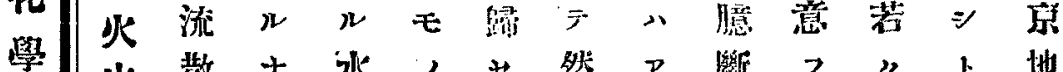
會 誌士一夫隨 第壤 四 =理上テ酷得底厂ル源當

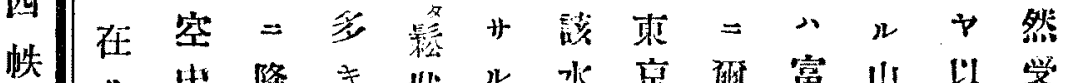

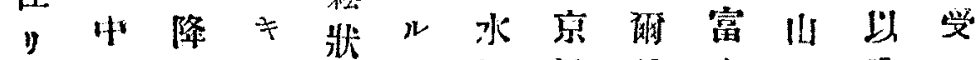
$\bar{T}=下 \neg++$ 源近吩士脈篇》

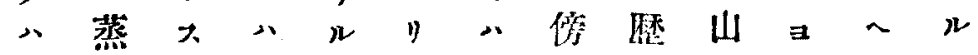

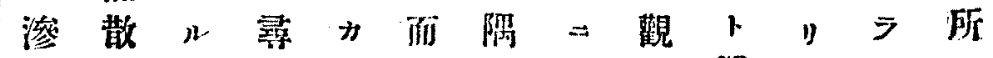
下入雨管故 シ田ア大溥泩》,

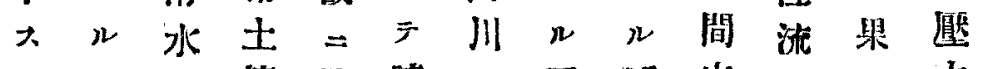

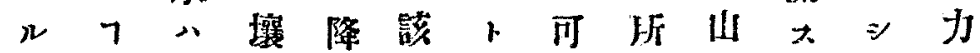
水八之, 雨臺茤 $\neq=1 n=$

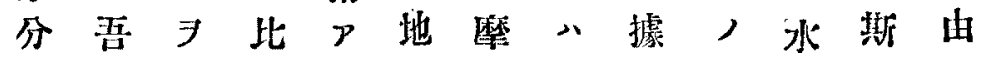

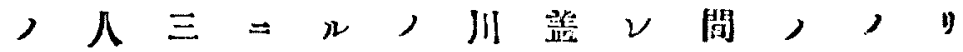
遥, 分子每士卜疑入 $\Rightarrow$ 地所

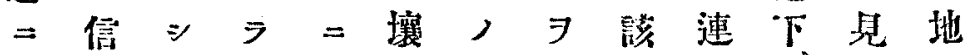
百多認 $テ$ 少容

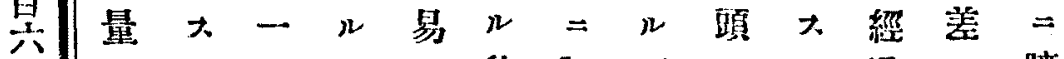
十ナル 八可二彼延可 $⿻$ 過八纷 儿川 $\neg$ 中心收火大ラ遠山來ン

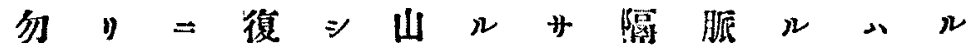

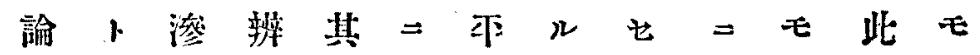




\section{为 報 析分水井}

二十時も七是

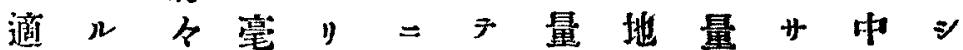
入王, モ何由海、下 川停其》" $y$ 正水一可淩今 算水水, 水源 $=$ 用日之n二七八

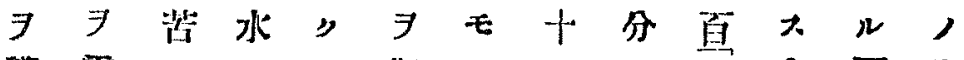
獲需三人束觀, 三一号今雨生

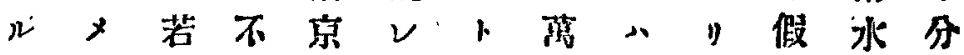

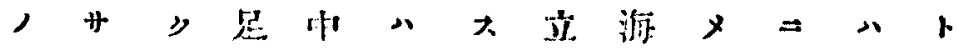
最几八二地本人市

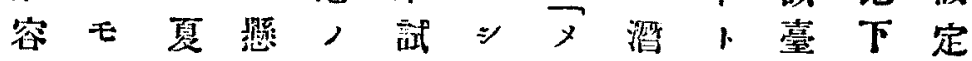
易常期念東, $+\Rightarrow$ ， 万阿分 几能旱几高析 事》魀 9 低成 In 其 $=$ 哭 7 果 是, 由七阔》 十咓”夫

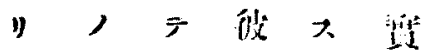
軟诚, 䢔二 和水水處踩

$\Rightarrow=$ 檘 $\Rightarrow$ 琵

シ 蜼, 製

テヌ修造ル 瑟 繙工一

二如 $=$ 㙋 蒸 遇 㸠不七畏創 鑊 便 テ 大見 注地 卜 万、, 溉 $ル ル \approx$ 面過モ こモ其皘 シ 大 $\approx,$, 四 $=$ 過 和皮拾終十 此假分里 = 力 ，女八和隅儿 大八地斿田 畧 则下卫川 半右二”荡卜 分水溼亏暨信 八分入䝁川下 承, 三年及而 京筷而了, 海

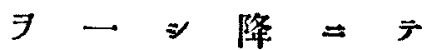
經 日 雨 泿 斯 過, 其, 入》 
交報析分承韭

萁


マ 1 佦 此

\#八物, $>$ 酸确硫鹽曹加苦石

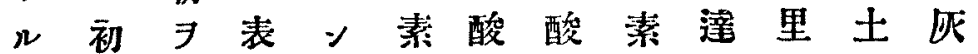
$\exists$ 八 溶 $\Rightarrow$ 乇 見一取據二

$n \geqslant \rightarrow \nu \rightarrow$

$\sim$ 七 $八$

シ 增 7 該

但师荠地

$=$ 大 尔 下

曹 $\nu+$ 水

䢰泟止,

$\therefore$ 潮 $\exists$ 其

潮 次明,

增 = 証上微

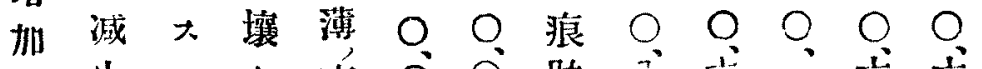

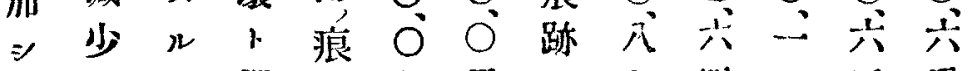

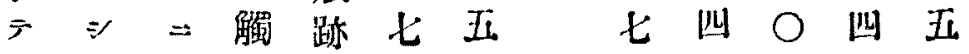
其曹 足 接

量挚儿大

$=$ 小鮮

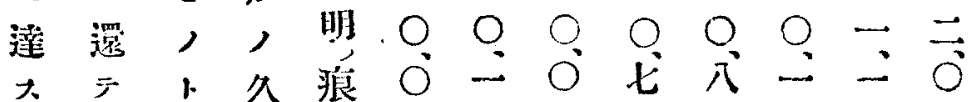
$\nu$ 徐 $大$ 跡 九五二五八共 $\bigcirc$ 五 八年キ

監 增 石 $=$

化加应迲微

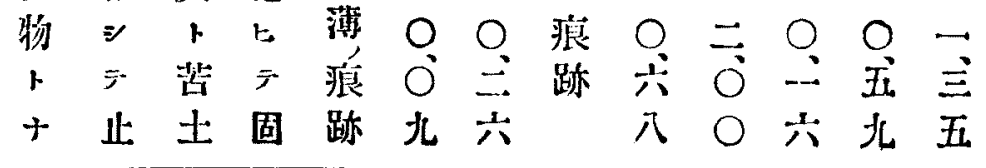


文報析分氷井

ヨ八有 $\Rightarrow$ ４中

乘

得地 ナ示テルテ

宁

>下片 世何二現

楛 $7 ル 二$ 似存

所較彼由》大

$=$ 些,

命

柉少遠

㹥

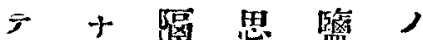

第

一川十 7 惄 $\Rightarrow$

[4]

定 $=n \Rightarrow$ 小

十緣山是水 $\boldsymbol{P}$

的失

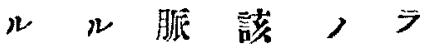

能七 $九$ 地流大

八ノも進

\#\#仰氷学

ル或》川ッ霓

$\Rightarrow$ 八 其 $\Rightarrow=$

由灭以，随石

其 $F$ 源 七庅

カ乙乙 $7 \approx$ 及

今 源水密 激炭

容小心 $心$ 次

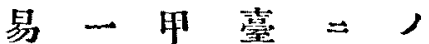

百
\pm

$\Rightarrow+$ 水地娍一

之心 之, 少部

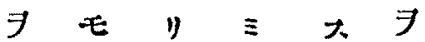

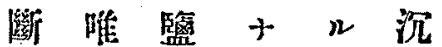

定監 素

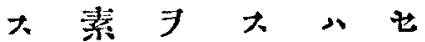

ル赤含 前果 シ 